THE GREEN, BLUE AND GREY WATER FOOTPRINT OF RICE FROM BOTH A PRODUCTION AND CONSUMPTION PERSPECTIVE 



\title{
THE GREEN, BLUE AND GREY WATER FOOTPRINT OF RICE FROM BOTH A PRODUCTION AND CONSUMPTION PERSPECTIVE
}

\author{
A.K. ChAPAGAIN ${ }^{1}$ \\ A.Y. HOEKSTRA ${ }^{2}$
}

MARCH 2010

Value of Water Research Report Series No. 40

\footnotetext{
${ }^{1}$ WWF-UK, Godalming, United Kingdom, email: achapagain@wwf.org.uk

${ }^{2}$ University of Twente, Enschede, Netherlands, email: a.y.hoekstra@utwente.nl
}

The Value of Water Research Report Series is published by UNESCO-IHE Institute for Water Education, Delft, the Netherlands in collaboration with

University of Twente, Enschede, the Netherlands, and Delft University of Technology, Delft, the Netherlands 



\section{Contents}

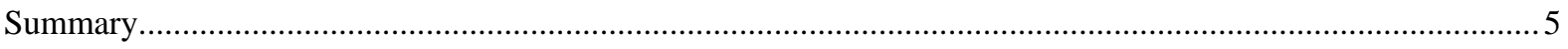

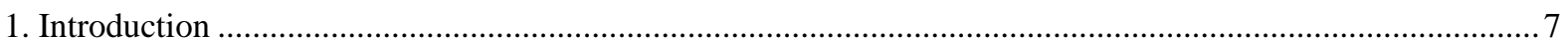

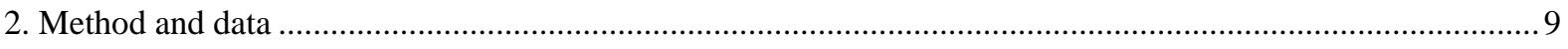

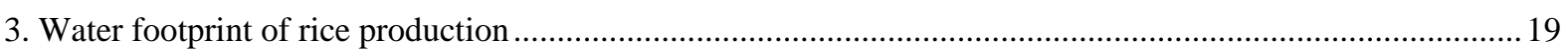

4. International virtual water flows related to rice trade ...........................................................................2

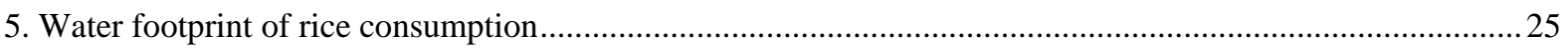

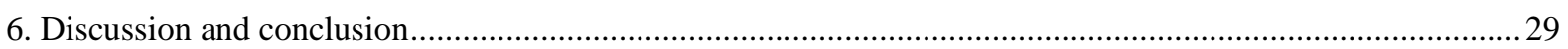

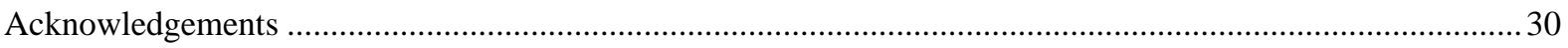

References

Appendix A: Data on main regions of rice production within major rice producing countries..........................35

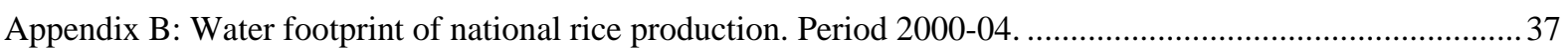

Appendix C. Water footprint of national rice consumption. Period 2000-04 .................................................42

Appendix D. Virtual water fluxes related to the international trade in rice products. Period 2000-04................48 



\section{Summary}

The aim of this report is to make a global assessment of the green, blue and grey water footprint of rice, using a higher spatial resolution than earlier studies and applying local data on actual irrigation. Evapotranspiration from rice fields is calculated with the CROPWAT model; the distinction between green and blue water evapotranspiration is based on data on precipitation and irrigation. Water pollution from N-fertilisers is estimated based on application rates. The calculated green, blue and grey water footprints of paddy rice are converted into estimations of the green, blue and grey water footprints of derived rice products on the basis of product and value fractions. International virtual water flows related to trade in rice products are estimated by multiplying trade volumes by their respective water footprints in the exporting countries. We take both a production and a consumption perspective. Per nation, the total water footprint of rice production is estimated by aggregating the water footprints per production region. Next, for each nation, the water footprint of rice consumption is estimated by looking in which regions of the world the rice that is consumed in that nation is produced. The water footprint of rice consumption in a nation is calculated by aggregating the water footprints in the regions where the rice consumed in a nation is grown. For rice importing countries, the water footprint related to rice consumption is thus partly (or fully) outside the country itself.

In the period 2000-04, the global average water footprint of paddy rice was $1325 \mathrm{~m}^{3} /$ ton (48\% green, $44 \%$ blue, and $8 \%$ grey), which is much lower than previous estimates. There is about $1025 \mathrm{~m}^{3} /$ ton of percolation in rice production. The global water footprint of rice production is estimated to be 784 billion $\mathrm{m}^{3} / \mathrm{yr}$. The ratio of green to blue water varies greatly, both over time and space. In countries like India, Indonesia, Viet Nam, Thailand, Myanmar and the Phillippines, the green water fraction is substantially larger than the blue water fraction. In the USA, however, the blue water fraction is 3.7 times the green water fraction; in Pakistan 5.6 times.

During the period 2000-04, the global virtual water flows related to international rice trade added up to a total of 31 billion $\mathrm{m}^{3} / \mathrm{yr}$ (45\% green, $47 \%$ blue, and $8 \%$ grey). The blue water component in the average rice export is a bit higher than in the average rice production.

The consumption of rice products in the EU27 alone is responsible for the annual evaporation of 2,279 $\mathrm{Mm}^{3}$ of water and polluted return flows of $178 \mathrm{Mm}^{3}$ around the globe, mainly in India, Thailand, the USA and Pakistan. The water footprint of global rice consumption creates relatively low stress on the water resources in India compared to that in the USA and Pakistan, as in the latter cases rice is extensively irrigated with scarce blue water resources. 



\section{Introduction}

Rice is one of the major crops feeding the world population and is most important in South Asia and Africa. Large irrigation projects are often constructed to meet the water demand in rice production. As a result, rice is one of the largest water consumers in the world. This report quantifies how much fresh water is being used to produce rice globally, distinguishing between two different sources: irrigation water withdrawn from gound- or surface water (blue water) and rainwater (green water). It also quantifies the volume of polluted water related to the use of nitrogen fertilisers in rice production (grey water).

Rainwater and irrigation water are necessary for rice growth in two ways: to maintain soil moisture and - in wet irrigation - to maintain the standing layer of water over the paddy field. In the major rice producing regions of the world, the crop is grown during the wet (monsoon) season, which reduces the irrigation demand by effectively using rainwater.

As much of the standing water in paddy fields percolates and re-charges groundwater and surface water, there is a substantial contribution to the local blue water availability. Percolation can be seen as a loss to the paddy field, but for the catchment area it is not considered as a loss, because the water can be captured and reused downstream (Bouman et al., 2007b). In some irrigation systems in flood plains with impeded drainage or systems in low lying deltas a continuous percolation can even create shallow ground water tables closer to the surface (Belder et al., 2004). Although the report focuses on the estimation of evapotranspiration from rice fields, it also estimates percolation flows, because evapotranspiration and percolation are both part of the soil water balance. 



\section{Method and data}

There are mainly two systems of rice production: wetland systems and upland systems. About $85 \%$ of the rice harvest area in the world is derived from wetland systems (Bouman et al., 2007b). About $75 \%$ of rice production is obtained from irrigated wetland rice (Bouman et al., 2007b). In Asia, rice fields are prepared by tillage followed by puddling. The soil layer is saturated and there is standing water during the entire growth period of the crop. In the USA, Australia, parts of Europe and some Asian countries, rice land is prepared dry and flooded later.

In the production database of the FAO (2009), 115 countries are reported as rice producers. During the period of 2000-04, the average annual global production of rice was 592 million metric tons with an average yield of 4.49 ton per hectare. The yield ranges from nearly 1 ton/ha (Jamaica, Micronesia, Congo, Brunei Darussalam, Comoros, Chad, Liberia, Mozanbique, Congo DR, Sierra Leone etc.) to 8.7 ton/ha (Australia). In India, the rainfed yield ranges between 0.5-1.6 ton/ha, whereas that of irrigated rice is 2.3-3.5 ton/ha (Gujja et al., 2007).

Table 1 presents production data for the thirteen countries with the largest average annual production during the period 2000-04. These countries account for more than $90 \%$ of the global production during this period. These thirteen countries together account for more than $82 \%$ of the total export of rice-equivalent globally. About 6$7 \%$ of the world rice production is traded internationally. A complete list of rice producing countries with production statistics is presented in Appendix B.

Table 1: Statistics for the thirteen largest rice producing countries during the period 2000-04.

\begin{tabular}{|c|c|c|c|c|c|c|c|}
\hline Country & $\begin{array}{r}\text { Average } \\
\text { production } \\
\text { (ton/yr) }\end{array}$ & $\begin{array}{c}\text { Global } \\
\text { share } \\
(\%)^{\star}\end{array}$ & $\begin{array}{r}\text { Average area } \\
\text { harvested } \\
(\mathrm{ha} / \mathrm{yr})^{\star}\end{array}$ & $\begin{array}{r}\text { Average } \\
\text { yield } \\
\text { (ton/ha)* }^{\star}\end{array}$ & $\underset{(\mathrm{kg} / \mathrm{ha})^{\star \star}}{\mathrm{N}}$ & $\begin{array}{c}\mathrm{P}_{2} \mathrm{O}_{5} \\
(\mathrm{~kg} / \mathrm{ha})^{\star \star}\end{array}$ & $\begin{array}{c}\mathrm{K}_{2} \mathrm{O} \\
(\mathrm{kg} / \mathrm{ha})^{\star \star}\end{array}$ \\
\hline China & $177,657,605$ & $30.0 \%$ & $28,670,030$ & 6.19 & 145 & 60 & 40 \\
\hline India & $126,503,280$ & $21.4 \%$ & $43,057,460$ & 2.93 & 67.7 & 24.2 & 9.4 \\
\hline Indonesia & $52,014,913$ & $8.8 \%$ & $11,642,899$ & 4.47 & 105 & 22 & 14 \\
\hline Bangladesh & $37,217,379$ & $6.3 \%$ & $10,641,271$ & 3.50 & 72 & 15 & 10 \\
\hline Viet Nam & $33,960,560$ & $5.7 \%$ & $7,512,160$ & 4.52 & 115 & 45 & 42 \\
\hline Thailand & $26,800,046$ & $4.5 \%$ & $10,038,180$ & 2.67 & 62 & 33 & 17 \\
\hline Myanmar & $22,581,828$ & $3.8 \%$ & $6,431,364$ & 3.51 & 35 & 12 & 4 \\
\hline Philippines & $13,322,327$ & $2.3 \%$ & $4,056,577$ & 3.28 & 51 & 15 & 11 \\
\hline Brazil & $11,068,502$ & $1.9 \%$ & $3,371,562$ & 3.28 & 40 & 50 & 30 \\
\hline Japan & $10,989,200$ & $1.9 \%$ & $1,706,000$ & 6.44 & 78 & 92 & 72 \\
\hline USA & $9,520,015$ & $1.6 \%$ & $1,285,671$ & 7.40 & 150 & 60 & 60 \\
\hline Pakistan & $6,910,650$ & $1.2 \%$ & $2,339,200$ & 2.95 & 52.2 & 6.9 & 0.2 \\
\hline Korea, Rep. & $6,808,450$ & $1.2 \%$ & $1,045,173$ & 6.51 & 110 & 70 & 80 \\
\hline Sub total & $535,354,755$ & $90.5 \%$ & $131,797,547$ & - & - & - & - \\
\hline Global total & $591,751,209$ & $100 \%$ & $150,666,851$ & 4.49 & - & - & - \\
\hline
\end{tabular}

* Source: FAO (2009).

** Average fertilizer use in rice cultivation. Source: IFA et al. (2002). 
The average fertilizer application rates for the top-13 rice producing countries have been taken from IFA et al. (2002) and are presented in Table 1. The use of animal manure reduces the need for chemical fertilizer use in crop fields. This is reflected in lower fertilization application rates in the database, mainly in developing countries. There is no readily available global dataset on use of animal manure in rice fields. Moreover, the spatial distribution of the fertilizer within a country is also not well known, therefore results on water pollution should be treated cautiously.

The reference crop evapotranspiration $\left(E T_{o}\right)$ and monthly average rainfall data for the concerned climate stations are taken from the CLIMWAT database (FAO, 1993) for all countries, but from FAOCLIM (FAO, 2001) for the USA. The $E T_{o}$ data in these databases are derived using the Penman-Monteith equation as described in Allen et al. (1998). Using the CROPWAT model (FAO, 1992), the crop evapotranspiration (ET $)$ and the available effective rainfall are calculated for the given set of data on $E T_{o}$, monthly rainfall, $K_{c}$ and the crop calendar. Rice crop coefficients are taken from Allen et al. (1998). Monthly data on rainfall and $E T_{o}$ are distributed within the month to obtain data per five days. As CROPWAT 4 (FAO, 1992) is not suitable to calculate the crop water requirement for rice (Clarke et al., 1998), we have used it only to get the values of $E T_{c}$ and the available effective rainfall for a time step of 5 days. For each of the thirteen countries, the crop evaporative demand $\left(E T_{c}\right)$ is calculated for each season of rice production in all the regions using the climate data for the concerned regions (Appendix A).

The CROPWAT model suggests a number of methods to estimate the effective rainfall and the method of the USDA SCS (Soil Conservation Service) is one of them. As this method does not take into account the soil type and the net depth of irrigation, it gives a lower estimation of effective rainfall compared to the water balance approach (Mohan et al., 1996) and is not very accurate. However, as the water balance approach is highly data demanding, the USDA SCS method is widely used in estimating the effective rainfall in agriculture water management (Cuenca, 1989; Jensen et al., 1990). We have also chosen the USDA SCS method for the present study. The USDA SCS equations to estimate effective rainfall are:

$P_{\text {eff }}=P_{\text {total }} / 125 \times\left(125-0.2 \times P_{\text {total }}\right) \quad$ for $P_{\text {total }} \leq 250 \mathrm{~mm}$

$P_{\text {eff }}=\left(125+0.1 \times P_{\text {total }}\right) \quad$ for $P_{\text {total }} \geq 250 \mathrm{~mm}$

where $P_{\text {eff }}$ is the effective rainfall and $P_{\text {total }}$ the total rainfall in the concerned period.

For rice cultivation in wetland systems, paddy fields are prepared and the soil is kept saturated. The common practice is to first prepare land by puddling. This is done by saturating the soil layer for one month prior to sowing. The volume of water (SAT) necessary for this stage is assumed to be $200 \mathrm{~mm}$ as suggested by Brouwer and Heibloem (1986). As lowland rice is grown in a standing layer of water, there is a constant percolation and seepage loss during this period. Percolation loss (PERC) is primarily a function of soil texture. It varies from 2 $\mathrm{mm}$ /day (heavy clay) to $6 \mathrm{~mm} /$ day for sandy soil. As rice is mostly grown in soil with more clayey texture, for the present study we have taken $2.5 \mathrm{~mm}$ /day as an average (Brouwer and Heibloem, 1986) for the entire period of rice cultivation except for the last 15 days when the field is left to dry out for easy harvesting. A water layer 
is established during transplanting or sowing and maintained throughout the growing season. Although the volume of water needed for maintaining the water layer (WL) is available for percolation losses and to meet the evaporative demand of the crop during the last phase of paddy growth, it is necessary to get this volume of water at the beginning of the crop period (Figure 1). In this study, it is assumed that a water layer of $100 \mathrm{~mm}$ is established in the month of sowing. A time step of five days is chosen for the calculation. The total water demand (WD) is calculated by adding $\mathrm{ET}_{\mathrm{c}}$, WL, SAT and PERC for each time step.

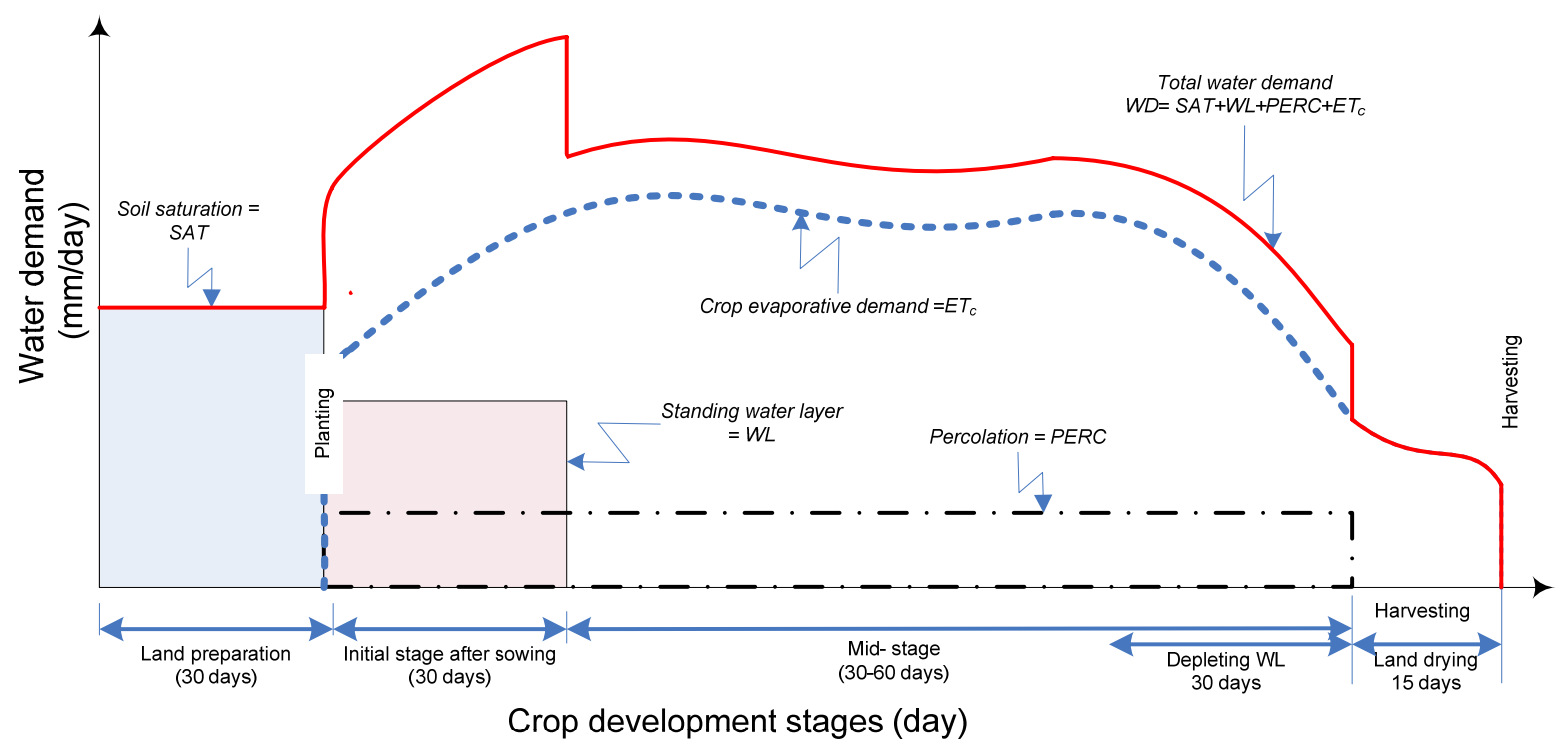

Figure 1. The schema used to estimate the water demand at different stages of crop growth.

For the last 15 days prior to the harvesting when the land is left to dry out, the volume of water required for evaporation is supplied by the effective rainfall in the period and any residual soil moisture maintened from the previous stages. Approximately 30 days before the land is left to dry out, the standing layer of water is slowly left to deplete without any augmenting water supply to maintain the water layer. This practice makes the best use of water supplied to maintain the WL in the previous stages. The method, thus, accounts the storage of water in time either as soil moisture or as water layer over the rice field.

Any residual soil moisture after the harvest is not included in the water footprint estimation. It is assumed that the initial soil moisture before the land preparation is negligible. It is also assumed that the contribution of capillary rise from the shallow ground water table in the rice fields is negligible. The net inflow and outflow of the overland runoff from the bunded rice fields are assumed to be zero as well. The schema to measure the depth of water available (WA) for use in different stages of crop development is presented in Figure 2.

The water use in the rice fields is calculated for each 5-day cumulative period using the schema as presented in Figure 3. If the total water demand $W D$ is less than total water available $W A$, green water use is equal to the demand WD. In cases where the WD exceeds $W A$, the deficit is to be met by irrigation water supply. This deficit is called irrigation water demand. If a paddy field is $100 \%$ irrigated, it is assumed that the 'blue water' use in crop production is equal to the deficit. For areas equipped with partial irrigation coverage, the blue water use is estimated on a pro-rata basis. 


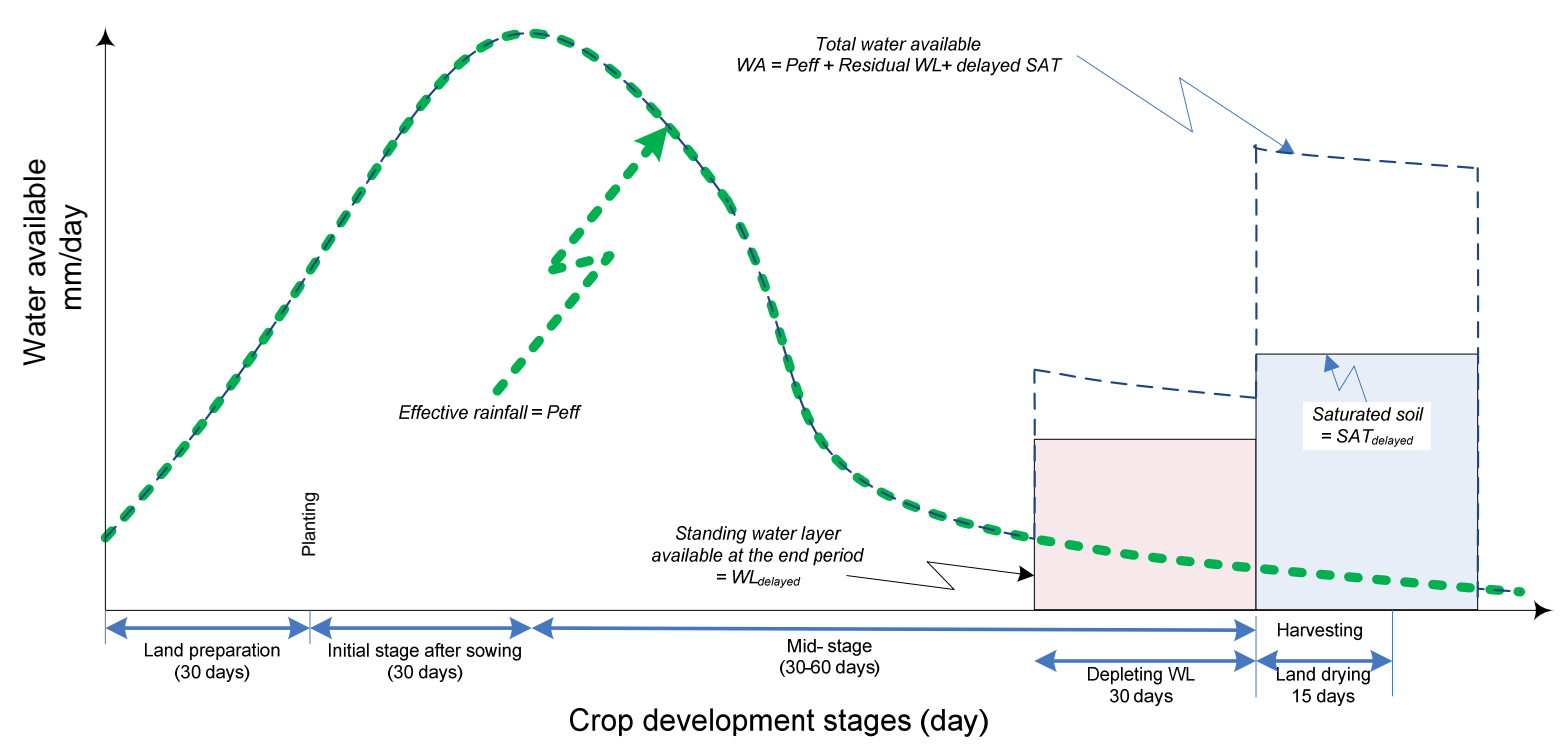

Figure 2. The schema used to estimate the total water available at different stages of crop growth.

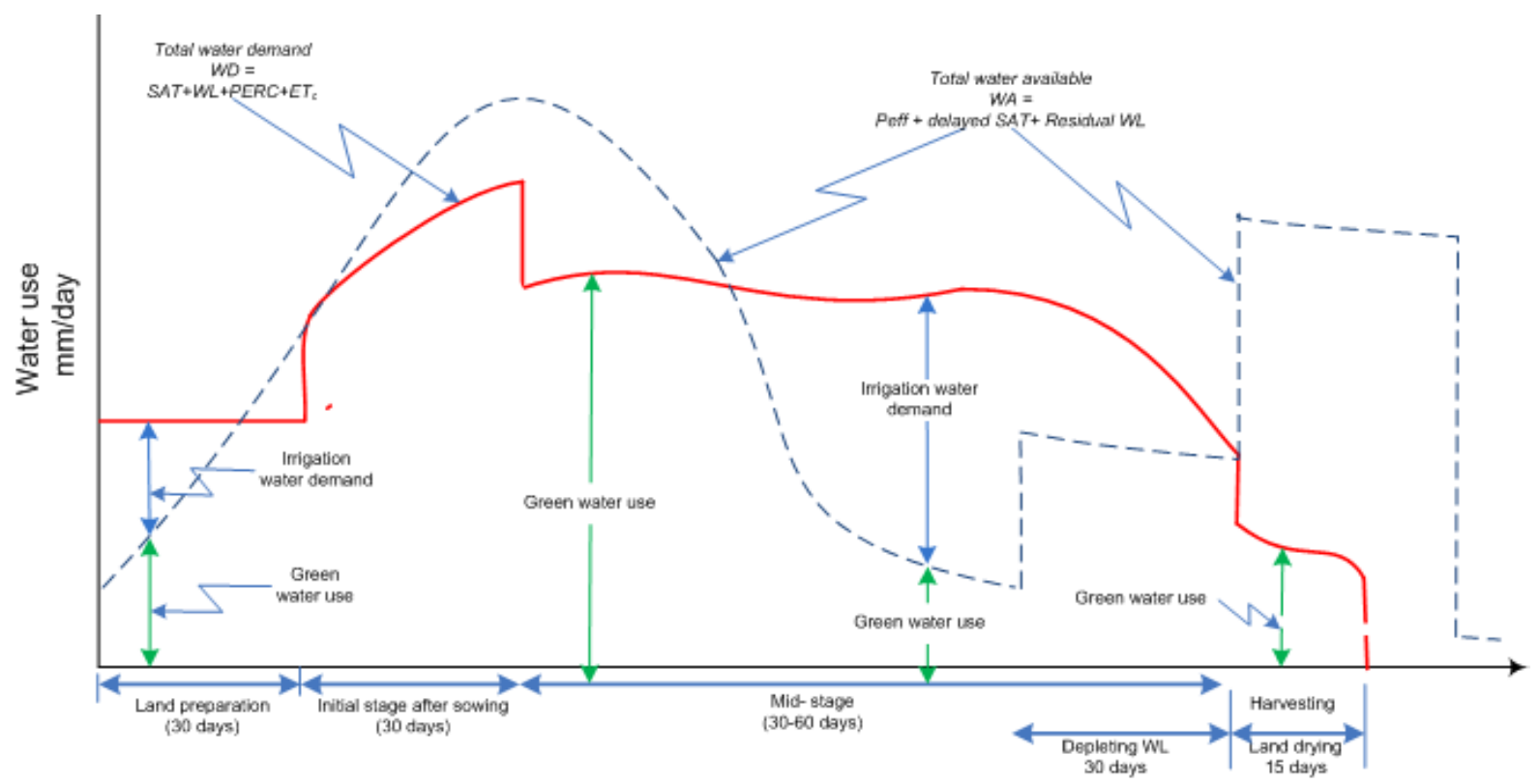

Figure 3. Distinguishing the green water use and irrigation water demand.

In order to show the sort of detail we have applied, we give an example here for India. There are two major rice production seasons in India, known as Kharif (monsoon season) and Rabi (dry season). For the period of 200004 , the share of Kharif production to the gross national production is $86 \%$ and the remaining $14 \%$ is from Rabi. The data for harvested area, crop period, irrigated share, crop yield and total production are taken from the Directorate of Rice Development (2001). Crop water use depends on the crop calendar adopted and it is difficult to analyse multiple crop calendars that possibly exist in a region. The study assumes a single representative calendar is valid per region in India. The planting and harvesting time for the crop are assumed to be at the average of these dates gathered from various sources such as the Directorate of Rice Development (2001), IRRI (2006), and Maclean et al. (2002). The major Kharif rice producing regions in India are Uttar Pradesh, West Bengal, Punjab, Bihar, Andhra Pradesh, Tamil Nadu, Madhya Pradesh, Orissa and Assam, producing 85\% of 
the national Kharif rice production (Appendix A). The major Rabi rice producing regions are Andhra Pradesh, West Bengal, Tamil Nadu, Karnataka and Orissa, producing 92\% of the national Rabi rice production. The state-wise data for irrigated area are taken from the Directorate of Rice Development (2001). The rice production in Rabi is assumed to be fully irrigated and the remainder of the total irrigated area is attributed to the Kharif rice. The irrigation water requirement $\left(\mathrm{m}^{3} / \mathrm{ha}\right)$ and the green water use $\left(\mathrm{m}^{3} / \mathrm{ha}\right)$ are calculated per state for the major rice producing regions. For the remaining regions, the average irrigation water requirement and green water use are calculated based on the data for the major regions. Blue water use is calculated by multiplying the irrigation requirement with the irrigated area in each season per state. The green water use in irrigated areas is calculated by multiplying the green water use $\left(\mathrm{m}^{3} / \mathrm{ha}\right)$ by the total area in each season.

The example of India is followed for each of the other twelve countries. The planting and harvesting dates for all of the crop producing regions in these countries are chosen based on the major crop season in these regions (USDA, 1994). The climate stations representing the production regions, regional share of production (\%) to the total national production and irrigation coverage per region are presented for all countries in Appendix A. For each production region, we have estimated the green water use, irrigation demand and blue water use based on whether it is a 'wetland system' or an 'upland system'. The national averages of green and blue water use are calculated based on the data per region and the share of production of each region to the total national production.

\section{The water footprint of paddy rice}

The water footprint is the volume of water used to produce a particular good, measured at the point of production. A number of studies have been conducted to quantify the water footprint of a large variety of different crop products (Hoekstra, 2003; Chapagain and Hoekstra, 2004; Oki and Kanae, 2004 ; Hoekstra and Hung, 2005; Hoekstra and Chapagain, 2008). These studies provided a broad-brush to the global picture as the primary focus of these studies was to establish a first estimate of global virtual water flows and/or national water footprints. More detailed crop-specific studies have been produced such as for cotton (Chapagain et al., 2006), tea and coffee (Chapagain and Hoekstra, 2007), tomato (Chapagain and Orr, 2009) and sugar beet, sugar cane and maize (Gerbens-Leenes and Hoekstra, 2009). This is the first detailed global assessment of rice.

The calculation framework to quantify the water footprint of rice is based on Hoekstra and Chapagain (2008) and Hoekstra et al. (2009). The water footprint of a product ( $\mathrm{m}^{3} / \mathrm{unit}$ ) is calculated as the ratio of the total volume of water used $\left(\mathrm{m}^{3} / \mathrm{yr}\right)$ to the quantity of the production (ton/yr). The water footprint has three components: the green water footprint (evaporation of water supplied from the rain in crop production), blue water footprint (evaporation of the irrigation water supplied from surface and renewable ground water sources) and the grey water footprint (volume of fresh water polluted in the production process). Most studies on the calculation of water footprints of products have taken the two evaporative components only (i.e. green and blue water footprint), excluding the grey water footprint. In an earlier study, Chapagain and Hoekstra (2004) have assumed a constant percolation loss of $300 \mathrm{~mm}$ of water per year from the rice field and added that to the total water footprint of rice. This is inconsistent, however, with the approach taken for other products in the same 
study. In the present study, a clear distinction between the evaporation and percolation is a made. The percolation flow is not included in the water footprint.

The volume of polluted water depends both on the pollutant load and the adopted concentration standard for surface and ground water bodies for individual categories of pollutants. To avoid double counting, the grey water use in crop production should take the maximum of any of these requirements for individual pollutant categories. Due to data limitations, this study looks at nitrogen $(\mathrm{N})$ as a representative element for estimations of the grey water footprint.

Nitrogen recovery rarely exceeds 30-40\% in wet-land rice production systems (De Datta, 1995). In these systems, rice is primarily grown in clay soils thus restricting the nitrogen loss by leaching. Loss of nitrogen by runoff is also controlled in most rice fields. Ammonia $\left(\mathrm{NH}_{3}\right)$ volatisation and denitrification are recognized as major nitrogen loss mechanisms that affect the efficiency of urea and other $\mathrm{N}$ fertilisers in irrigated wetland rice (De Datta, 1995). In general, irrigated systems have higher fertiliser application rates than rainfed systems. For example, in India during the period of 2003-04, the fertiliser application in irrigated crop land amounted to 22\% of the total national fertiliser application, whereas that for the rainfed crops was only 9.6\% (Table 2). In Indonesia 52\% of the fertilizers used are applied to rice (FAO, 2005b).

Table 2. Fertiliser used for rice production in India during 2003-04.

\begin{tabular}{lrrrrrrr} 
& Gross harvested area & $\begin{array}{r}\text { Share in national fertiliser } \\
\text { consumption }\end{array}$ & & \multicolumn{4}{c}{ Fertiliser consumption (kg/ha) } \\
& $(1,000,000 \mathrm{ha})$ & $(\%)$ & $\mathrm{N}$ & $\mathrm{P}_{2} \mathrm{O}_{5}$ & $\mathrm{~K}_{2} \mathrm{O}$ & Total \\
\hline Irrigated & 24.0 & 22.2 & 103.4 & 32.8 & 18.8 & 155 \\
Rainfed & 20.7 & 9.6 & 56.6 & 14.5 & 6.5 & 77.6 \\
National & 44.7 & 31.8 & 81.7 & 24.3 & 13.1 & 119.1 \\
\hline
\end{tabular}

Source: FAO (2005a).

In wetland rice cultivation, the global $\mathrm{NH}_{3}$ loss to the atmosphere from the annual use of 12 million tonnes of mineral fertilizer (N) amounts to 2.3 million ton N/yr, or $20 \%$ of the $\mathrm{N}$ application, and $97 \%$ of this occurs in developing countries (FAO and IFA, 2001). For a continuous flooding rice system, the denitrification is never more than $10 \%$. For an intermittent fallow system it is up to $40 \%$ (Fillery and Vlek, 1982). As reported in Xing and Zhu (2000), there is about $0-5 \%$ of leached nitrogen from upland rice fields, though this varies from 10 to $30 \%$ if the surface runoff is taken into account. Zhu et al. (2000) have suggested the leaching losses to be $2 \%$ of the application rate. The magnitude of nitrogen leaching depends on soil conditions (irrigation frequencies, rainfall pattern, soil texture, percolation rate, etc) and methods of fertilization application (application rate, time, agronomical practices etc). However, as the focus of this report is rather global in nature, a first-order estimation of the volume of water polluted is made following the method presented in Chapagain et al. (2006). In this study, we have taken a flat rate of nitrogen leaching equal to $5 \%$ of the nitrogen application rate.

Since 1991, the European Union (EU) member states have had to comply with the Nitrates Directive which aims to protect ground and surface waters from pollution by nitrogen (nitrates) originating from agriculture. The 
permissible limit of nitrates in surface and ground water bodies as set by the EU is $50 \mathrm{mg}$ nitrate- $\mathrm{NO}_{3}$ per litre. The standards recommendation by the EPA (2005) is $10 \mathrm{mg} / \mathrm{l}$ (measured as nitrogen). We have taken the number from the EU Nitrate Directives to estimate the volume of water necessary to dilute leached nitrogen to the permissible limit.

\section{The water footprint of processed rice}

Paddy is the most primary form of rice. The actual rice kernels are encased in an inedible and protective hull. Brown rice or husked rice has the outer hull removed, but still retains the bran layers that give it a characteristic tan color and nut-like flavor. Brown rice is edible but has a chewier texture than white rice. Milled rice is also called white rice. Milled rice is the product after milling which includes removing all or part of the bran and germ from the paddy.

On average, rice varieties are composed of roughly $20 \%$ rice hull, $11 \%$ bran, and $69 \%$ starchy endosperm. The endosperm is also known as the total milled rice which contains whole grains or head rice, and broken grains. Rice milling can be a one step, two steps or multi-step process. In a one step milling process, husk and bran removal are done in one pass and milled or white rice is produced directly out of paddy. In a two-step process, husk and bran are removed separately, and brown rice is produced as an intermediate product. In multi-stage milling, rice goes through a complex set of different processing steps. The maximum milling recovery (total milled rice obtained out of paddy, expressed as a weight percentage) is $69-70 \%$ depending on the rice variety. The global average of milling recovery is only $67 \%$.

The water footprint of the primary rice crop is attributed to the processed products on the basis of so-called product fractions and value fractions (Chapagain and Hoekstra, 2004; Hoekstra et al., 2009). The product fraction is defined as the weight of a derived product obtained per ton of root product. For example, if one ton of paddy rice (the root product) produces 0.85 ton of husked rice (the derived product), the product fraction of husked rice is 0.85 . If there are more than two products obtained while processing a root product, we need to distribute the water footprint of the root product over its derived products based on value fractions and product fractions. The value fraction of a derived product is the ratio of the market value of the derived product to the aggregated market value of all the derived products obtained from the root product. To estimate the water footprint of various rice products originating from paddy, a product tree (Figure 4) is constructed showing the various products at various levels (primary, secondary and tertiary) along with their product fraction and value fraction. Based on these, the water footprints of the various derived rice products are calculated. 


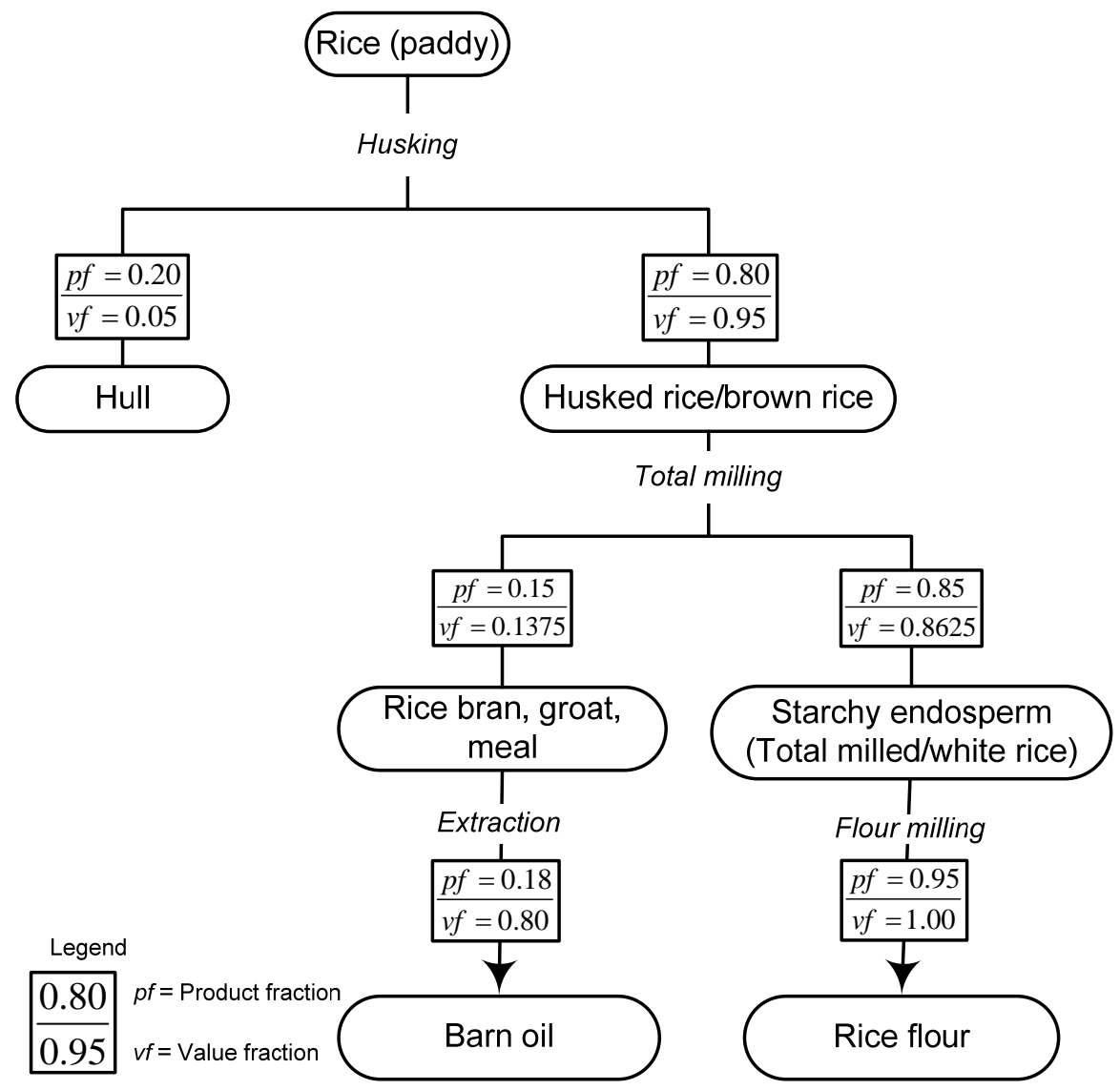

Figure 4. Product tree of rice showing value fraction and product fraction per rice processing stage.

\section{Calculation of international virtual water flows}

The virtual water flow between two nations is the volume of water that is being transferred in virtual form from one place to another as a result of product trade. The virtual water flows between nations related to trade in rice products have been calculated by multiplying commodity trade flows (ton/yr) by their associated water footprint $\left(\mathrm{m}^{3} /\right.$ ton) in the exporting country (Chapagain and Hoekstra, 2008). The virtual water export of a country is the volume of water used to make export goods or services.Similarly, the virtual water import of a country is the volume of virtual water imported through goods or services. Data on international trade of rice products are taken from PCTAS (ITC, 2006) for the period 2000-04 ${ }^{1}$.

\section{Calculation of the water footprint related to rice consumption in a country}

The water footprint of national consumption can be classified into an internal and an external component. The internal water footprint of rice consumption refers to the consumption and pollution of national water resources to domestically produce rice for own consumption. The external water footprint of rice consumption refers to water used in the countries from where rice is imported for national consumption. The internal and external water footprint are assessed following the scheme shown in Figure 5.

\footnotetext{
${ }^{1}$ The trade data on rice imports by Papua N. Guinea is erroneous in PCTAS and thus discarded in estimating the international virtual water flows with all of its trading partner countries.
} 
The green, blue and grey water footprint of rice / 17

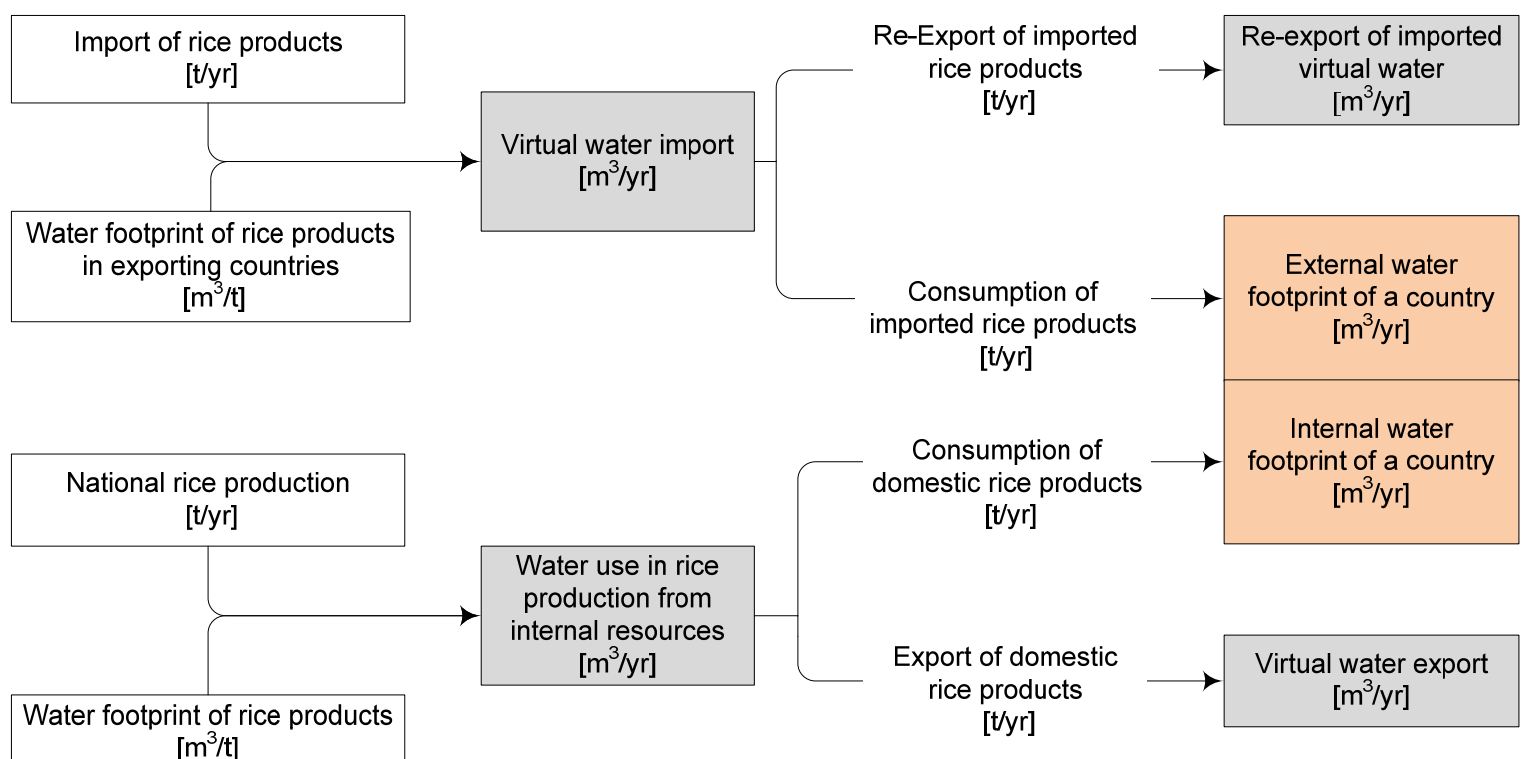

Figure 5. The calculation scheme for assessing the water footprint of nationional consumption of rice products. 



\section{Water footprint of rice production}

The calculated average water depth used in rice production in each of the thirteen major rice producing countries is presented in Table 3. In the USA, the evaporation is relatively high, at the same time the effective rainfall is much lower, making the irrigation volume one of the highest. Rice fields in both the USA and Pakistan are $100 \%$ irrigated, making the blue water footprint high in these countries.

Table 3. Depth of water used in rice production ( $\mathrm{mm} / \mathrm{yr}$ ) for the 13 major rice-producing countries. Period 2000-04.

\begin{tabular}{lccccc}
\hline & \multicolumn{2}{c}{ Evaporation } & Pollution & \multicolumn{2}{c}{ Percolation } \\
Country & Green & Blue & Grey & Rain water & Irrigation water \\
\hline China & 228 & 302 & 73 & 209 & 277 \\
India & 314 & 241 & 34 & 231 & 178 \\
Indonesia & 260 & 217 & 53 & 226 & 188 \\
Bangladesh & 192 & 202 & 36 & 192 & 202 \\
Viet Nam & 139 & 92 & 58 & 190 & 125 \\
Thailand & 252 & 149 & 31 & 210 & 125 \\
Myanmar & 297 & 133 & 18 & 268 & 120 \\
Japan & 219 & 258 & 39 & 224 & 264 \\
Philippines & 277 & 139 & 26 & 254 & 127 \\
Brazil & 260 & 220 & 20 & 227 & 192 \\
USA & 168 & 618 & 75 & 104 & 383 \\
Korea, Rep. & 232 & 253 & 55 & 198 & 216 \\
Pakistan & 124 & 699 & 26 & 73 & 412 \\
\hline
\end{tabular}

The total water use $\left(\mathrm{m}^{3} / \mathrm{yr}\right)$ for rice production in each country is calculated by multiplying the national harvested area of rice crops (ha/yr) with the corresponding depth of water (mm/yr) used in paddy fields. The water footprint of rice production is the sum of water evaporated from the rice fields and the volume of water polluted in the process. The results are presented in Table 4. It also presents the volume of water percolated or left over as residual soil moisture after the crop harvest in the fields. Total water use is the sum of the water footprint and percolation. The water footprint refers to a real loss to the catchment, while the percolation is actually not a loss to the catchment.

Table 5 shows the water footprint and percolation per unit of paddy rice produced $\left(\mathrm{m}^{3} / \mathrm{ton}\right)$. The figures follow from dividing total national water footprint and percolation related to rice production ( $\left.\mathrm{m}^{3} / \mathrm{yr}\right)$ by the gross national paddy production per year (ton/yr). The volume of water evaporated per ton of rice is quite similar to the evaporation per ton of wheat, as also noted in Bouman and Toung (2001). The higher evaporation rates per hectare as a result of the standing water layer in rice fields are apparently compensated for by the relatively higher yields of rice (Bouman et al., 2007b). 
Table 4. Total national water footprint of rice production and percolation of water in the thirteen major riceproducing countries (billion $\mathrm{m}^{3} / \mathrm{yr}$ ). Period 2000-04.

\begin{tabular}{lcccccccc}
\hline & \multicolumn{3}{c}{ National water footprint of rice } & \multicolumn{3}{c}{ Percolation and residual soil } & \multicolumn{2}{c}{$\begin{array}{c}\text { Total water use } \\
\text { moisture }\end{array}$} \\
Production (evaporation + pollution) & \multicolumn{3}{c}{ (WF + percolation) } \\
\hline China & Green & Blue & Grey & Total & Green & Blue & Total & - \\
India & 136.3 & 86.5 & 20.8 & 172.5 & 60.0 & 79.5 & 139.5 & 312.0 \\
Indonesia & 30.3 & 25.3 & 6.1 & 61.7 & 26.3 & 21.9 & 48.2 & 432.9 \\
Bangladesh & 20.4 & 21.5 & 3.8 & 45.7 & 20.5 & 21.5 & 42.0 & 110.0 \\
Viet Nam & 10.5 & 6.9 & 4.3 & 21.7 & 14.3 & 9.4 & 23.7 & 87.7 \\
Thailand & 25.2 & 15.0 & 3.1 & 43.3 & 21.1 & 12.5 & 33.6 & 45.3 \\
Myanmar & 19.1 & 8.5 & 1.1 & 28.8 & 17.2 & 7.7 & 24.9 & 76.9 \\
Japan & 3.7 & 4.4 & 0.7 & 8.8 & 3.8 & 4.5 & 8.3 & 53.7 \\
Philippines & 11.2 & 5.6 & 1.0 & 17.9 & 10.3 & 5.2 & 15.5 & 17.1 \\
Brazil & 8.8 & 7.4 & 0.7 & 16.8 & 7.6 & 6.5 & 14.1 & 33.4 \\
USA & 2.2 & 8.0 & 1.0 & 11.1 & 1.3 & 4.9 & 6.3 & 31.0 \\
Korea, Rep. & 2.4 & 2.6 & 0.6 & 5.6 & 2.1 & 2.3 & 4.3 & 17.3 \\
Pakistan & 2.9 & 16.3 & 0.6 & 19.9 & 1.7 & 9.6 & 11.3 & 10.0 \\
\hline
\end{tabular}

Table 5. Water footprint and percolation per unit of paddy rice produced $\left(\mathrm{m}^{3} / \mathrm{ton}\right)$ in the thirteen major riceproducing countries. Period 2000-04.

\begin{tabular}{|c|c|c|c|c|c|c|c|}
\hline \multirow[b]{2}{*}{ Country } & \multicolumn{4}{|c|}{ Water footprint } & \multicolumn{3}{|c|}{ Percolation } \\
\hline & Green & Blue & Grey & Total & $\begin{array}{l}\text { Rain } \\
\text { water }\end{array}$ & $\begin{array}{l}\text { Irrigation } \\
\text { water }\end{array}$ & Total \\
\hline China & 367 & 487 & 117 & 971 & 338 & 448 & 785 \\
\hline India & 1077 & 826 & 116 & 2020 & 794 & 609 & 1403 \\
\hline Indonesia & 583 & 487 & 118 & 1187 & 505 & 422 & 927 \\
\hline Bangladesh & 549 & 577 & 103 & 1228 & 550 & 578 & 1128 \\
\hline Viet Nam & 308 & 203 & 127 & 638 & 420 & 277 & 697 \\
\hline Thailand & 942 & 559 & 116 & 1617 & 787 & 467 & 1253 \\
\hline Myanmar & 846 & 378 & 50 & 1274 & 763 & 341 & 1103 \\
\hline Japan & 341 & 401 & 61 & 802 & 348 & 409 & 757 \\
\hline Philippines & 844 & 423 & 78 & 1345 & 775 & 388 & 1163 \\
\hline Brazil & 791 & 670 & 61 & 1521 & 691 & 585 & 1276 \\
\hline USA & 227 & 835 & 101 & 1163 & 141 & 517 & 658 \\
\hline Korea, Rep. & 356 & 388 & 84 & 829 & 303 & 331 & 634 \\
\hline Pakistan & 421 & 2364 & 88 & 2874 & 248 & 1394 & 1642 \\
\hline $\begin{array}{l}\text { Average based on } \\
\text { weighted production data }\end{array}$ & 632 & 584 & 109 & 1325 & 535 & 490 & 1025 \\
\hline $\begin{array}{r}\text { Average based on } \\
\text { weighted export data }\end{array}$ & 618 & 720 & 112 & 1450 & 522 & 538 & 1060 \\
\hline
\end{tabular}

Table 5 also shows the global average water footprint of rice, calculated based on the share of national production of the top-13 rice producing countries to the total global production. Since the export share of these 
13 countries to the total export volume during the period 2000-04 differs widely, the global average water footprint of rice paddy is also calculated weighing the export share of these countries. As the top-13 largest rice producing countries contribute $82 \%$ to the global share of rice export, the difference between these two averages is not big. Global average results presented in the following sections are based on the global average water footprint based on production. Table 6 shows the global average water footprints of rice products.

Table 6. The global average water footprint of rice products ( $\mathrm{m}^{3} /$ ton). Period 2000-04.

\begin{tabular}{llrrr}
\hline PC-TAS code & Product description & Green & Blue & Grey \\
\hline 100610 & Rice in the husk (paddy or rough) & 632 & 584 & 109 \\
100620 & Rice, husked (brown) & 750 & 693 & 130 \\
110314 & Rice groats and meal & 688 & 636 & 119 \\
100630 & Rice, semi-milled, milled, whether or not polished or glazed & 761 & 704 & 132 \\
100640 & Rice, broken & 761 & 704 & 132 \\
110230 & Rice flour & 801 & 741 & 139 \\
\hline
\end{tabular}

Using the global average water footprint of paddy calculated and the production data for the rest of the countries, the global water footprint of rice production is estimated to be 784 billion $\mathrm{m}^{3} / \mathrm{yr}$ ( $48 \%$ green, $44 \%$ blue and $8 \%$ grey) (Figure 6). The volume of water percolated in the rice fields plus any residual soil moisture left in the field after rice harvest is equal to 607 billion $\mathrm{m}^{3} / \mathrm{yr}$, about half of which (52\%) is sustained by rainfall in the rice field. Including percolation, the total blue water use in the rice field becomes 636 billion $\mathrm{m}^{3} / \mathrm{yr}$, which is the number often quoted in the literature while referring to the total water used in rice production. If we add the total water footprint and the percolation water volume, it is equal to 1,391 billion $\mathrm{m}^{3} / \mathrm{yr}$, which is nearly the same as the global water use in rice fields (1,359 billion $\left.\mathrm{m}^{3} / \mathrm{yr}\right)$ as reported in Chapagain and Hoekstra (2004). Water footprints of rice production for all countries are presented in Appendix B.

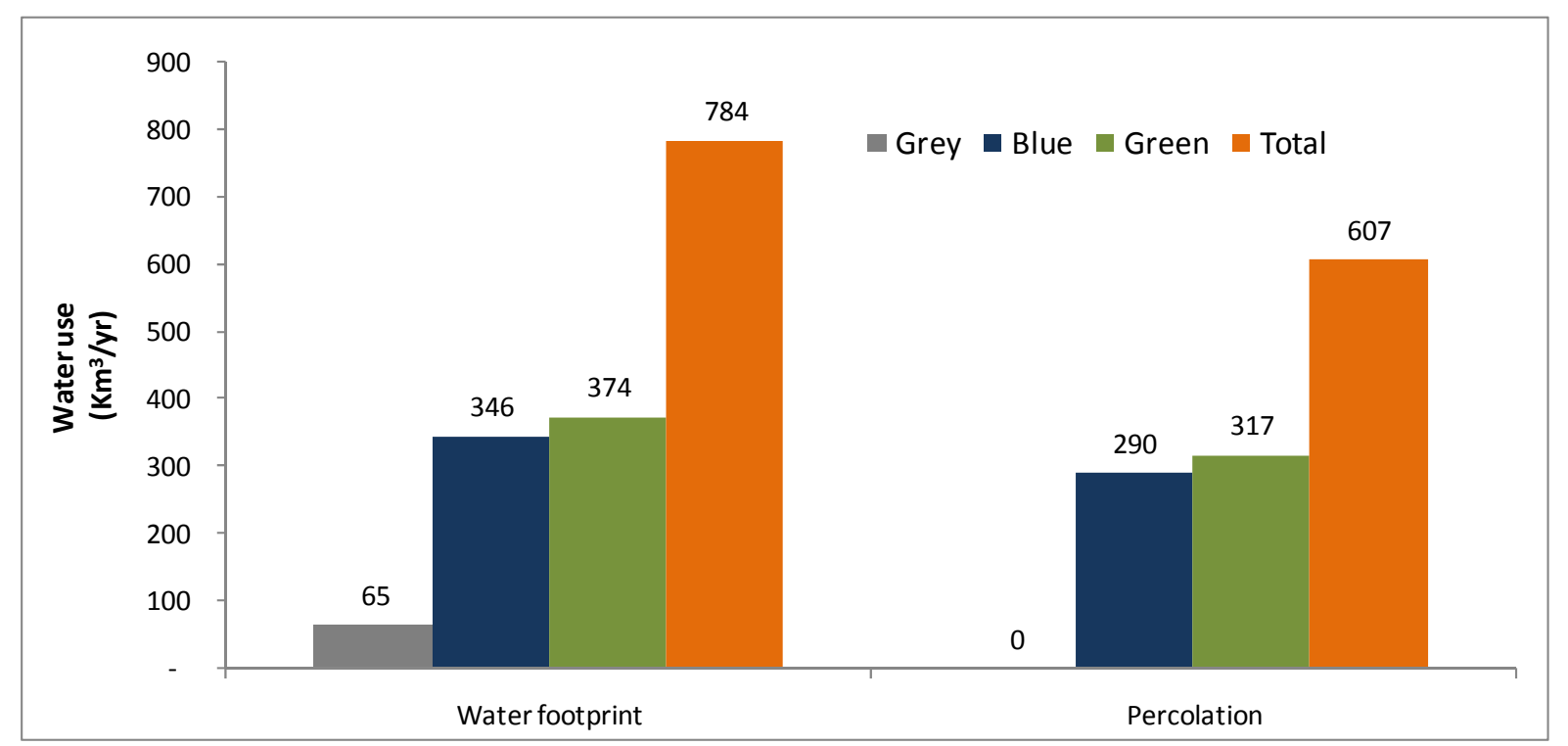

Figure 6. The global water footprint of rice production and the total volume of water percolated in rice fields (billion $\mathrm{m}^{3} / \mathrm{yr}$ ). Period 2000-04. 



\section{International virtual water flows related to rice trade}

International trade in rice during the period 2000-04 resulted in a total international virtual water transfer of 31.1 billion $\mathrm{m}^{3} / \mathrm{yr}$ (45\% green water, $47 \%$ blue water, $8 \%$ grey water). This means that international rice trade is linked to the evaporation of 28.7 billion $\mathrm{m}^{3}$ of water per year with an additional 2.4 billion $\mathrm{m}^{3}$ of fresh water being polluted each year in the exporting countries.

The top ten largest gross virtual water exporters are Thailand (9,627 $\left.\mathrm{Mm}^{3} / \mathrm{yr}\right)$, India (5,185 $\left.\mathrm{Mm}^{3} / \mathrm{yr}\right)$, USA (3,474 $\left.\mathrm{Mm}^{3} / \mathrm{yr}\right)$, Pakistan (2,923 $\left.\mathrm{Mm}^{3} / \mathrm{yr}\right)$, China $\left(1,296 \mathrm{Mm}^{3} / \mathrm{yr}\right)$, Viet Nam $\left(1,233 \mathrm{Mm}^{3} / \mathrm{yr}\right)$, Italy $(1,048$ $\mathrm{Mm}^{3} / \mathrm{yr}$ ), Uruguay (899 $\mathrm{Mm}^{3} / \mathrm{yr}$ ), Egypt (644 $\mathrm{Mm}^{3} / \mathrm{yr}$ ) and Australia (599 $\mathrm{Mm}^{3} / \mathrm{yr}$ ) covering nearly $87 \%$ of the total virtual water export international trade in rice products globally. The largest gross importers are Nigeria (2,944 $\left.\mathrm{Mm}^{3} / \mathrm{yr}\right)$, Indonesia (1,637 $\left.\mathrm{Mm}^{3} / \mathrm{yr}\right)$, Iran (1,506 $\left.\mathrm{Mm}^{3} / \mathrm{yr}\right)$, Saudi Arabia $\left(1,429 \mathrm{Mm}^{3} / \mathrm{yr}\right)$, South Africa (1,348 $\mathrm{Mm}^{3} / \mathrm{yr}$ ), Senegal (1,346 $\mathrm{Mm}^{3} / \mathrm{yr}$ ), Brazil (1,010 $\left.\mathrm{Mm}^{3} / \mathrm{yr}\right)$, Japan (988 $\mathrm{Mm}^{3} / \mathrm{yr}$ ) and Philippines (979 $\mathrm{Mm}^{3} / \mathrm{yr}$ ) covering about $42 \%$ of the total import. Appendix D shows gross virtual water export and import for all countries.

Net imports of water are calculated by subtracting the gross export volume of water from the gross import volume of water, and vice versa for net exports. The largest net exporters and net importers are shown in Table 7.

Table 7. Largest net-exporters and net-importers of virtual water related to the international trade of rice products.

\begin{tabular}{|c|c|c|c|c|c|c|c|c|c|}
\hline \multicolumn{5}{|c|}{ Largest net-exporters ( $\left.\mathrm{Mm}^{3} / \mathrm{yr}\right)$} & \multicolumn{5}{|c|}{ Largest net-importers $\left(\mathrm{Mm}^{3} / \mathrm{yr}\right)$} \\
\hline & Green & Blue & Grey & Total & & Green & Blue & Grey & Total \\
\hline Thailand & 5,607 & 3,327 & 691 & 9,625 & Nigeria & 1,528 & 1,204 & 211 & 2,943 \\
\hline India & 2,764 & 2,119 & 298 & 5,181 & Indonesia & 788 & 682 & 149 & 1,620 \\
\hline Pakistan & 428 & 2,405 & 90 & 2,923 & Iran & 670 & 721 & 97 & 1,489 \\
\hline USA & 237 & 2,172 & 245 & 2,654 & Saudi Arabia & 650 & 694 & 82 & 1,426 \\
\hline Viet Nam & 595 & 392 & 246 & 1,233 & Senegal & 756 & 482 & 107 & 1,344 \\
\hline Uruguay & 428 & 395 & 74 & 897 & South Africa & 701 & 509 & 88 & 1,298 \\
\hline Italy & 417 & 370 & 74 & 861 & Philippines & 490 & 386 & 103 & 979 \\
\hline Egypt & 307 & 284 & 53 & 644 & Brazil & 433 & 459 & 83 & 974 \\
\hline China & 87 & 410 & 106 & 602 & Japan & 340 & 514 & 83 & 937 \\
\hline Australia & 215 & 196 & 40 & 451 & Malaysia & 399 & 349 & 66 & 814 \\
\hline
\end{tabular}

The average annual blue virtual water import during the study period was 14.6 billion $\mathrm{m}^{3} / \mathrm{yr}$ and the average green virtual water import was 14.1 billion $\mathrm{m}^{3} / \mathrm{yr}$. The total average annual virtual water flows including the pollution component was 31.1 billion $\mathrm{m}^{3} / \mathrm{yr}$. The share of green virtual water to the total global virtual water flows related to the international trade of rice products is $45 \%$, and that of blue water is $47 \%$.

The total virtual water flows related to international trade of rice according to Chapagain and Hoekstra (2004) was 64 billion $\mathrm{m}^{3} / \mathrm{yr}$ for the period 1997-2001 (Table 8). This is quite comparable with the estimation in this study, which is 54 billion $\mathrm{m}^{3} / \mathrm{yr}$ when percolation is also included. However, the calculation in Chapagain and 
Hoekstra (2004) does not separate the green and blue components, and is based on national average climate data. The earlier study included percolation in the estimate of the total virtual water flows. The former study gave an overestimation as it was assumed that the total crop water requirements in the rice fields are always met either by rainfall or by irrigation water supply, which is not the case in general. On the other hand, the earlier estimate does not include the volume of water polluted in the process.

Table 8. Global international virtual water flows by rice product $\left(\mathrm{Mm}^{3} / \mathrm{yr}\right)$.

\begin{tabular}{|c|c|c|c|c|c|c|}
\hline \multirow[b]{2}{*}{ Product description } & \multicolumn{5}{|c|}{ Current study * } & \multirow{2}{*}{$\begin{array}{r}\text { Chapagain and } \\
\text { Hoekstra } \\
\text { Total virtual } \\
\text { water flows }\end{array}$} \\
\hline & Green & Blue & Grey & Percolation & Total & \\
\hline Rice flour & 108 & 89 & 17 & 162 & 375 & 511 \\
\hline Rice groats and meal & 6 & 5 & 1 & 9 & 21 & 24 \\
\hline Rice in the husk (paddy or rough) & 662 & 1,392 & 192 & 1,430 & 3,675 & 2,776 \\
\hline Rice, broken & 2,121 & 1,800 & 351 & 3,311 & 7,583 & 10,853 \\
\hline Rice, husked (brown) & 1,417 & 1,715 & 258 & 2,423 & 5,813 & 5,302 \\
\hline Rice, semi-milled or wholly milled & 9,768 & 9,591 & 1,561 & 15,447 & 36,367 & 44,741 \\
\hline Total & 14,081 & 14,592 & 2,379 & 22,782 & 53,834 & 64,207 \\
\hline
\end{tabular}

* Period 2000-04. The assessment includes grey water.

** Period 1997-2001. The assessment does not separate different components of virtual water flows. It excludes grey water, but includes percolation in rice fields. 


\section{Water footprint of rice consumption}

The largest consumer of rice in terms of water is India, followed by China, Indonesia, Bangladesh, Thailand, Myanmar, Viet Nam, the Philippines and Brazil. The composition of the water footprint related to rice consumption for the fifteen largest countries is presented in Table 9. The per-capita water footprint of rice consumption is quite high in Thailand (547 $\mathrm{m}^{3} / \mathrm{cap} / \mathrm{yr}$ ) compared to India (239 $\mathrm{m}^{3} / \mathrm{cap} / \mathrm{yr}$ ), Indonesia (299 $\mathrm{m}^{3}$ /cap/yr), China (134 m³/cap/yr) and the USA (29 m³/cap/yr). This variation is also because the diet contains more rice in some countries compared to others. The complete list of countries with their water footprints related to rice consumption is presented in Appendix C.

Table 9. Top-15 of countries with the largest water footprints related to rice consumption (Mm³/yr). Period 2000-04.

\begin{tabular}{lrrrrr} 
& \multicolumn{3}{c}{ Total water footprint $\left(\mathrm{Mm}^{3} / \mathrm{yr}\right)$} & & Water footprint per capita \\
\cline { 2 - 5 } & Green & Blue & Grey & Total & $\left(\mathrm{m}^{3} /\right.$ cap/yr $)$ \\
\hline India & 133,494 & 102,425 & 14,385 & 250,305 & 239 \\
China & 65,154 & 86,050 & 20,680 & 171,884 & 134 \\
Indonesia & 31,097 & 26,005 & 6,262 & 63,364 & 299 \\
Bangladesh & 20,560 & 21,574 & 3,846 & 45,980 & 317 \\
Thailand & 19,640 & 11,654 & 2,421 & 33,714 & 547 \\
Myanmar & 18,989 & 8,483 & 1,118 & 28,591 & 612 \\
Viet Nam & 9,860 & 6,496 & 4,074 & 20,430 & 256 \\
Philippines & 11,736 & 6,020 & 1,137 & 18,893 & 238 \\
Brazil & 9,186 & 7,869 & 757 & 17,812 & 99 \\
Pakistan & 2,480 & 13,935 & 521 & 16,936 & 117 \\
Japan & 4,084 & 4,923 & 748 & 9,755 & 77 \\
USA & 1,924 & 5,779 & 719 & 8,422 & 29 \\
Egypt & 3,467 & 3,203 & 599 & 7,269 & 105 \\
Nigeria & 3,478 & 3,005 & 548 & 7,031 & 54 \\
Korea, R & 2,491 & 2,732 & 592 & 5,814 & 122 \\
\hline
\end{tabular}

From the perspective of food security as well as from the viewpoint of sustainable consumption it is interesting to know where water footprints related to national consumption actually 'land'. We give here two examples, one for the USA and one for Europe. The total water footprint of the USA is $8,422 \mathrm{Mm}^{3} / \mathrm{yr}$. The internal waterfootprint is relatively large (93\% of the total water footprint) (Figure 7). The external water footprint of the USA is $591 \mathrm{Mm}^{3} / \mathrm{yr}$ and largely refers to water use in Thailand, India, Pakistan, China and Australia (Table 10).

In contrast to the USA, the sizes of the rice-consumption related internal and external water footprints of the EU27 are fairly comparable. Out of 5,335 $\mathrm{Mm}^{3} / \mathrm{yr}$, the internal component is 2,877 $\mathrm{Mm}^{3} / \mathrm{yr}$ and the external one is 2,457 $\mathrm{Mm}^{3} / \mathrm{yr}$ (Figure 8). More than $70 \%$ of the total external water footprint of the EU27 rests on eight countries, namely India, Thailand, the USA, Pakistan, Egypt, Guyana, China and Viet Nam. Figure 9 shows the external water footprint of the EU27 in each of these countries, distinguishing between the green, blue and grey water footprint. The largest share of the blue water footprint is for rice imported from the USA and Pakistan. 
Although the total footprint on India is the largest, a large fraction of it is made up of green water. Though the total footprint on Egypt, Guyana and Viet Nam is much lower than in Pakistan, the grey component on these countries is relatively higher than in Pakistan.

Table 10. External water footprint (EWF) of the USA by location ( $\left.\mathrm{Mm}^{3} / \mathrm{yr}\right)$. Period 2000-04.

\begin{tabular}{lrrrrr}
\hline & Green & Blue & Grey & Total & Share to the total EWF \\
\hline Thailand & 245 & 137 & 29 & 411 & $70 \%$ \\
India & 47 & 34 & 5 & 86 & $15 \%$ \\
Pakistan & 5 & 25 & 1 & 30 & $5 \%$ \\
China & 9 & 12 & 3 & 24 & $4 \%$ \\
Australia & 11 & 10 & 2 & 23 & $4 \%$ \\
Others & 8 & 7 & 1 & 17 & $3 \%$ \\
\hline Total & 326 & 225 & 41 & 591 & $100 \%$ \\
\hline
\end{tabular}

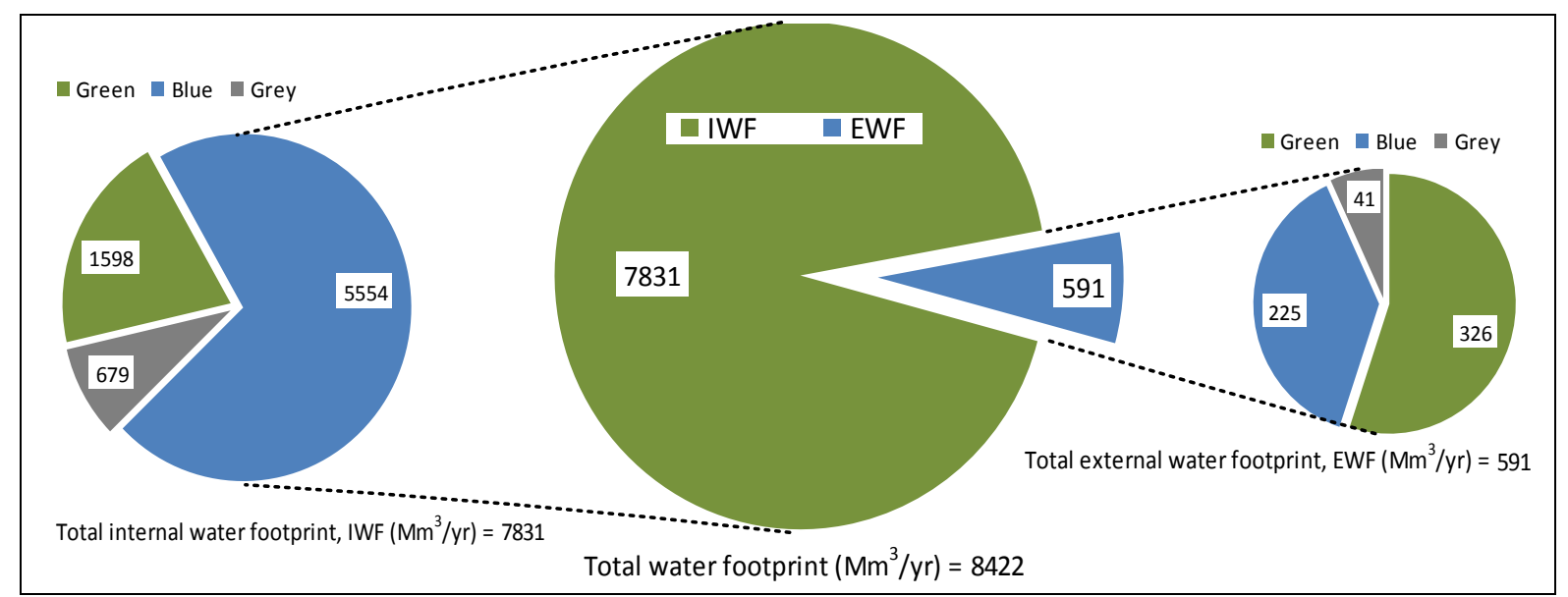

Figure 7. Water footprint of rice consumption in the USA (Mm³/yr). Period 2000-04.

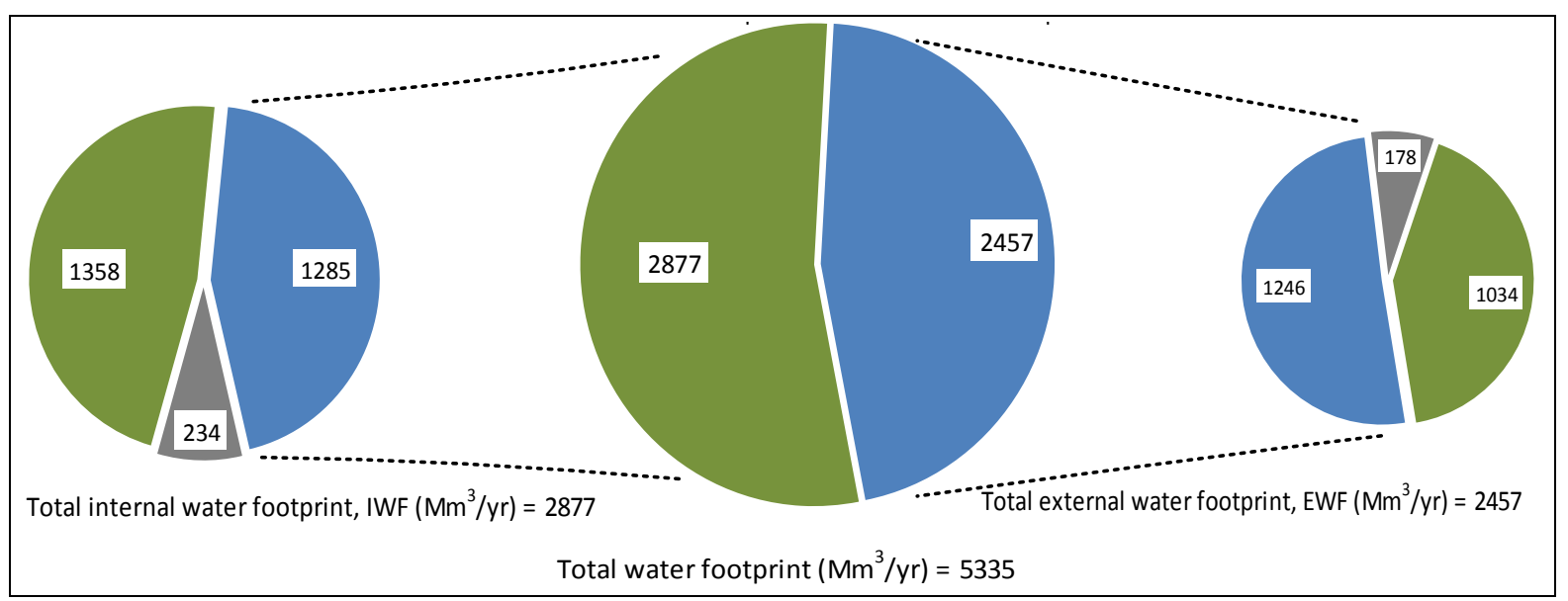

Figure 8. Water footprint of rice consumption in EU27 countries ( $\left.\mathrm{Mm}^{3} / \mathrm{yr}\right)$. Period 2000-04. 


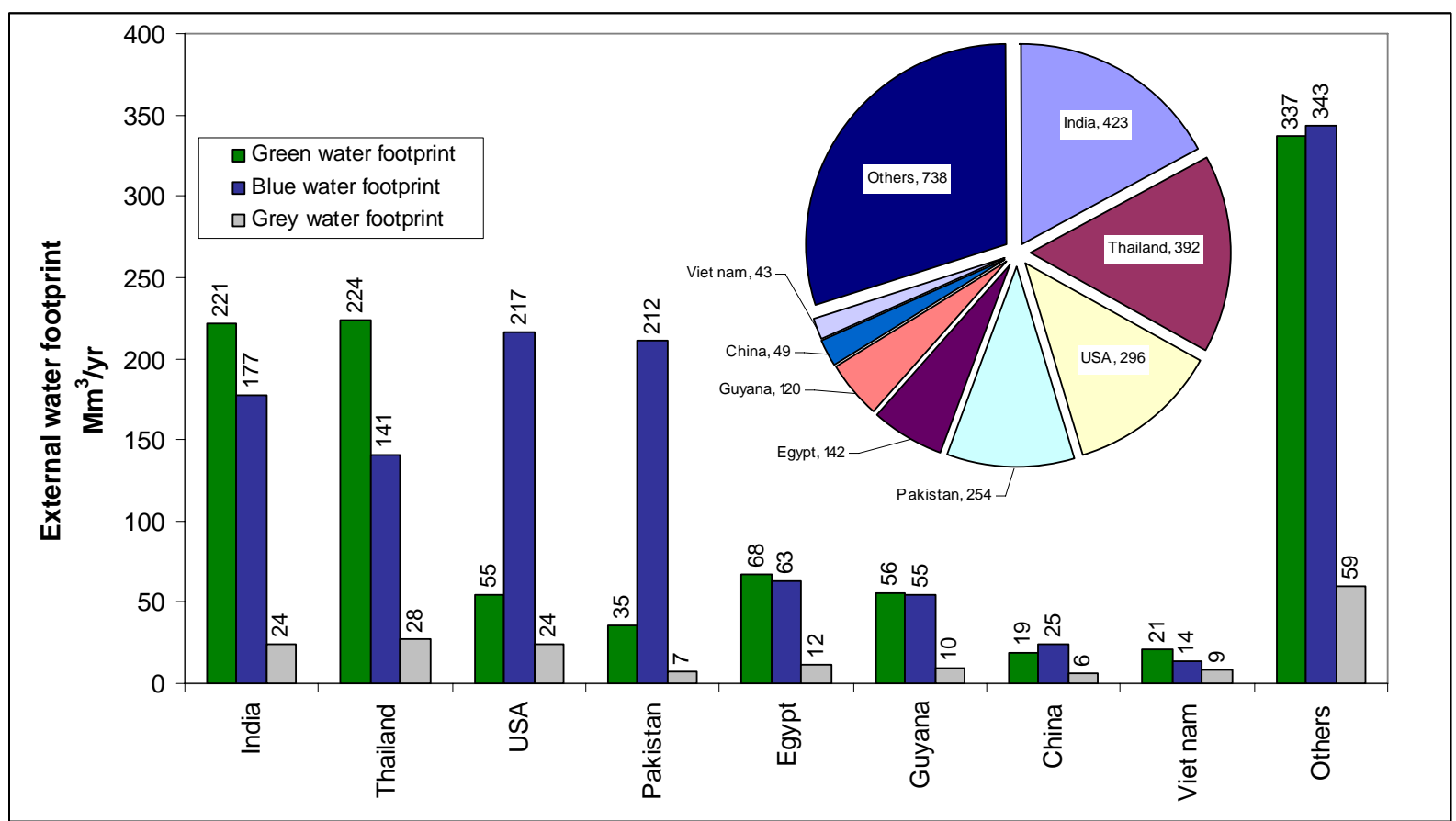

Figure 9. The external water footprint of rice consumption in the EU27. Period 2000-04. 



\section{Discussion and conclusion}

Rice is a staple food for three billion people (Maclean et al., 2002), especially in Southeast Asia, the Middle East, Latin America, and the West Indies. In terms of human nutrition and caloric intake, it provides nearly one fifth of the direct human calorie intake worldwide, making it the most important food crop (Smith, 1998; Zeigler and Barclay, 2008). Rice consumption exceeds $100 \mathrm{~kg}$ per capita annually in many Asian countries (compare for example with the USA average of $10 \mathrm{~kg}$ ) and is the principal food for most of the world's poorest people, particularly in Asia, which is home to $70 \%$ of those who earn less than $\$ 1$ a day (Zeigler and Barclay, 2008). Rice production is deeply rooted in the socio-political culture in Asia which nearly produces nearly $90 \%$ of the global rice (Bouman et al., 2007a).

The water footprint of rice production and consumption is quite significant in south Asian countries. However, in these countries most of the water footprint is rooted in the wet season, so that the contribution to water scarcity is relatively low in contrast to our general perception. Globally, there is nearly an equal share of green and blue water use in the total water footprint of rice. The green water footprint (rain) has a relatively low opportunity cost compared to the blue water footprint (irrigation water evaporated from the field). The environmental impact of the blue water footprint in rice production depends on the timing and location of the water use. It would need a dedicated analysis to estimate where and when blue water footprints in rice production constitute significant environmental problems, but from our results it is obvious that rice from the USA and Pakistan, where rice production heavily depends on blue water, will generally cause larger impacts per unit of product than rice from Viet Nam. From a sustainable-consumption perspective, for countries or regions that import a lot of rice for own consumption, it may be relevant to compare the local impacts of different rice sources. Besides, in international context one may address the question why rice consumers like in the EU do not cover the actual water cost (costs of water scarcity and water pollution) that occurs in the countries from where the rice is obtained. Since irrigation systems are generally heavily subsidized and water scarcity is never translated into a price, the economic or environmental costs of water are not contained in the price of rice. The water cost may actually largely vary from place to place, depending on whether the rice comes from e.g. India, Thailand, the USA, Pakistan or Egypt, and depending on whether the rice is produced in the dry or the wet period.

In probably a majority of cases, the green water footprint of rice production does not constitute significant negative environmental or economic impacts. Rainwater allocated for rice production generally has no opportunity cost, which means that alternative uses of the rain (natural vegetation, other crops) would not give higher benefits. Storing rainwater in the fields reduces or delays surface runoff and may thereby flatten peak flows in downstream rivers, which may be useful in the wet season during heavy rains. On the other hand, this mechanism may be absent or even reversed when rice fields are already full of water up to the point of overflow, in which case rain will become runoff very quickly. Although the green water footprint in rice production may not constitute significant environmental problems, reduction of the green water footprint at a global level is probably key in reducing the blue water footprint in rice production. Better use of rain wherever possible, that 
means increasing yields per drop of rainwater, will reduce the demand for rice from areas where blue water is a necessary input.

From an economic point of view, reducing percolation of blue water in the rice fields is relevant, because it will reduce costs of water supply. The environmental benefit is not so big, because percolated blue water will remain within the same catchment as from where it was abstracted. As a lot of water is percolating in the first phase of the land preparation, a number of water saving technologies have been suggested (Bouman et al., 2007a), which are effectively used in the Phillippines, India and China. The direct dry seeding method can increase the effective use of rainfall and reduce irrigation needs (Cabangon et al., 2002) in the phase of land preparation. Another way to reduce percolation from fileds is to use System of Rice Intensification (SRI). SRI suggests ways to improve rice yields with less water, the main highlight being that it uses water just enough to keep the roots moist all the time without any standing water at any time. The argument behind SRI is that the main benefit of flooding the rice plant is to check the proliferation of weeds, thereby saving labour (Gujja et al., 2007), which can be a favourable option where the supply is limited or scarce.

Rice production is a so-called diffuse source of pollution and hence difficult to mitigate. The option to have optimal application of fertiliser such that the application exactly matches the plant uptake, as in the case of dry crops, is not suitable in rice production. There is inevitably percolation leaching a part of the fertiliser along with it. The grey component of the water footprint can only be reduced with a reduction in the leaching of fertilizers and pesticides from the field, e.g. by increasing water use efficiency, using slow-release fertilizers and nitrification inhibitors, puddling the rice fields, planting catch and cover crops and using crop residues in situ (Choudhury and Kennedy, 2005). The loss of nitrogen may cause environmental and health problems. Although these problems cannot be alleviated completely, there are enough research findings that indicate that these problems can be minimized by a number of management practices (Choudhury and Kennedy, 2005). The fate of nitrogen in soil is mainly governed by different processes: plant-uptake, ammonia volatilization, de-nitrification and losses to surface (runoff) or ground water bodies (leaching). All these three processes are intertwined and it is hard to study them in isolation. A systematic analysis of fate of nitrogen should be carried out at field level to reveal any specific impacts on the system.

\section{Acknowledgements}

We thank the participants of the $4^{\text {th }}$ Marcelino Botín Foundation Water Workshop, held in Santander (Spain), 22-24 September 2009, and Stuart Orr and Biksham Guija from WWF International, for their critical feedbacks on drafts of this report. 


\section{References}

Allen, R. G., Pereira, L. S., Raes, D. and Smith, M. (1998) Crop evapotranspiration - Guidelines for computing crop water requirements. FAO Irrigation and Drainage Paper 56, Rome, Italy: FAO.

Belder, P., Bouman, B. A. M., Cabangon, R., Guoan, L., Quilang, E. J. P., Yuanhua, L., Spiertz, J. H. J. and Tuong, T. P. (2004) Effect of water-saving irrigation on rice yield and water use in typical lowland conditions in Asia. Agricultural Water Management 65(3): 193.

Bouman, B., Barker, R., Humphreys, E. and Tuong, T. P. (2007a) Rice: feeding the billions. In: Water for Food, Water for Life, D. Molden (ed.): Earthscan, London and International Water Management, Colombo.

Bouman, B. A. M., Humphreys, E., Tuong, T. P., Barker, R. and Donald, L. S. (2007b) Rice and Water. In: Advances in Agronomy, pp. 187-237. Academic Press.

Bouman, B. A. M. and Tuong, T. P. (2001) Field water management to save water and increase its productivity in irrigated lowland rice. Agricultural Water Management 49(1): 11.

Brouwer, C. and Heibloem, M. (1986) Irrigation water management, Training manuals - 3. Rome, Italy: Food and Agriculture Organization.

Cabangon, R. J., Tuong, T. P. and Abdullah, N. B. (2002) Comparing Water Input and Water Productivity of Transplanted and Direct-Seeded Rice Production Systems. Agricultural Water Management 57(1): 1113.

Chapagain, A. K. and Hoekstra, A. Y. (2004) Water footprints of nations. Value of Water Research Report Series No. 16, Delft, the Netherlands: UNESCO-IHE.

Chapagain, A. K. and Hoekstra, A. Y. (2007) The water footprint of coffee and tea consumption in the Netherlands. Ecological Economics 64(1): 109-118.

Chapagain, A. K. and Hoekstra, A. Y. (2008) The global component of freshwater demand and supply: An assessment of virtual water flows between nations as a result of trade in agricultural and industrial products. Water International 33(1): 19-32.

Chapagain, A. K., Hoekstra, A. Y., Savenije, H. H. G. and Gautam, R. (2006) The water footprint of cotton consumption: An assessment of the impact of worldwide consumption of cotton products on the water resources in the cotton producing countries. Ecological Economics 60(1): 186-203.

Chapagain, A. K. and Orr, S. (2009) An improved water footprint methodology linking global consumption to local water resources: A case of Spanish tomatoes. Journal of Environmental Management 90(2): 1219-1228.

Choudhury, A. T. M. A. and Kennedy, I. R. (2005) Nitrogen fertilizer losses from rice soil and control of environmental pollution problems. Communications in Soil Sciences and Plant Analysis 36: 16251639.

Clarke, D., Smith, M. and El-Askari, K. (1998) CropWat for Windows: User guide. Rome: Food and Agriculture Organization.

Cuenca, R. H. (1989) Irrigation system design: An engineering approach. Englewood Cliffs, New Jersey.: Prentice-Hall.

De Datta, S. K. (1995) Nitrogen transformations in wetland rice ecosystems. Fertilizer Research 42: 193-203.

Directorate of Rice Development (2001) Rice in India - A Handbook of Statistics. http://drdpat.bih.nic.in. 
EPA (2005) List of drinking water contaminants: Ground water and drinking water. www.epa.gov/safewater/mcl.html\#1.

FAO (1992) CROPWAT: A computer program for irrigation planning and management. Irrigation and Drainage Paper 46, Rome: Food and Agriculture Organization.

FAO (1993) CLIMWAT for CROPWAT: A climatic database for irrigation planning and management. Irrigation and Drainage Paper No. 49, Rome: Food and Agriculture Organization.

FAO (2001) FAOCLIM2: World-Wide Agroclimatic database. Rome: Food and Agriculture Organization.

FAO (2005a) Fertiliser use by crop in India. Rome: Food and Agriculture Organization.

FAO (2005b) Fertiliser use by crop in Indonesia. Rome: Food and Agriculture Organization.

FAO (2009) FAOSTAT database, http://faostat.fao.org/default.aspx

FAO and IFA (2001) Global estimates of gaseous emission of $\mathrm{NH}_{3}$, $\mathrm{NO}$ and $\mathrm{N}_{2} \mathrm{O}$ from agricultural land. Rome: Food and Agriculture Organization and International Fertilizer Industry Association.

Fillery, I. and Vlek, P. (1982) The significance of denitrification of applied nitrogen in fallow and cropped rice soils under different flooding regimes I. Greenhouse experimènts. Plant and Soil 65(2): 153.

Gerbens-Leenes, P. W. and Hoekstra, A. Y. (2009) The water footprint of sweeteners and bio-ethanol from sugar cane, sugar beet and maize. Value of Water Research Report Series No. 38, Delft: UNESCOIHE.

Gujja, B., Riddell, P., Goud, V. V., Dalai, S., Murty, M., Holland, R., Rupela, O. P., Rao, P., Kumar, M., Rao, K. and New Concept team (2007) More rice with less water: SRI - System of Rice Intensification. Dialogue on Water, Food and Environment. WWF.

Hoekstra, A.Y. (ed.) (2003) Virtual water trade: Proceedings of the International Expert Meeting on Virtual Water Trade, Value of Water Research Report Series No. 12, Delft: UNESCO-IHE.

Hoekstra, A. Y. and Chapagain, A. K. (2008) Globalization of water: Sharing the planet's freshwater resources. Oxford, UK: Blackwell.

Hoekstra, A. Y., Chapagain, A. K., Aldaya, M. M. and Mekonnen, M. M. (2009) Water footprint manual: State of the art 2009. Enschede, the Netherlands: Water Footprint Network.

Hoekstra, A. Y. and Hung, P. Q. (2005) Globalisation of water resources: International virtual water flows in relation to crop trade. Global Environmental Change 15(1): 45-56.

IFA, IFDC, IPI, PPI and FAO (2002) Fertilizer use by crop. www.fertilizer.org/ifa/statistics/crops/fubc5ed.pdf. IRRI (2006) World rice statistics. http://www.irri.org/science/ricestat/.

ITC (2006) PC-TAS version 2000-2004 in HS or SITC. Geneva: International Trade Centre.

Jensen, M. E., Burman, R. D. and Allen, R. G., eds. (1990) Evapotranspiration and irrigation water requirements. New York: Amer. Soc. Of Civil Engineers.

Maclean, J. L., Dawe, D. C., Hardy, B. and Hettel, G. P., eds. (2002) Rice Almanac. UK: CABI Publishing.

Mohan, S., Simhadrirao, B. and Arumugam, N. (1996) Comparative study of effective rainfall estimation methods for lowland rice. Water Resources Management V10(1): 35.

Oki, T. and Kanae, S. (2004) Virtual water trade and world water resources. Water Science \& Technology 49(7): 203-209.

Smith, B. D. (1998) The Emergence of Agriculture. New York: Scientific American Library, A Division of HPHLP. 
USDA (1994) Major world crop areas and climatic profiles. Washington DC: World Agricultural Outlook Board, U.S. Department of Agriculture.

Xing, G. X. and Zhu, Z. L. (2000) An assessment of N loss from agricultural fields to the environment in China. Nutrient Cycling in Agroecosystems 57(1): 67.

Zeigler, R. S. and Barclay, A. (2008) The relevance of rice. Rice 1(1): 3-10.

Zhu, J. G., Han, Y., Liu, G., Zhang, Y. L. and Shao, X. H. (2000) Nitrogen in percolation water in paddy fields with a rice/wheat rotation. Nutrient Cycling in Agroecosystems 57(1): 75. 



\section{Appendix A: Data on main regions of rice production within major rice producing countries}

\begin{tabular}{|c|c|}
\hline Country & $\begin{array}{l}\text { Crop season, major rice harvesting regions, share to the national production, irrigated area in } \\
\% \text { or ha, crop planting date, crop length in days and relevant climate stations }\end{array}$ \\
\hline Bangladesh & $\begin{array}{l}\text { Aus (14\%, 100\%, 15-Apr, 130d, Guwahati), T.Aman (40\%, 100\%, 01-Aug, 130d, Guwahati), } \\
\text { Aman broadcast (6\%, 100\%, 15-Apr, 115d, Guwahati), Boro (40\%, 100\%,01-Dec, 170d, } \\
\text { Guwahati) }\end{array}$ \\
\hline Brazil & 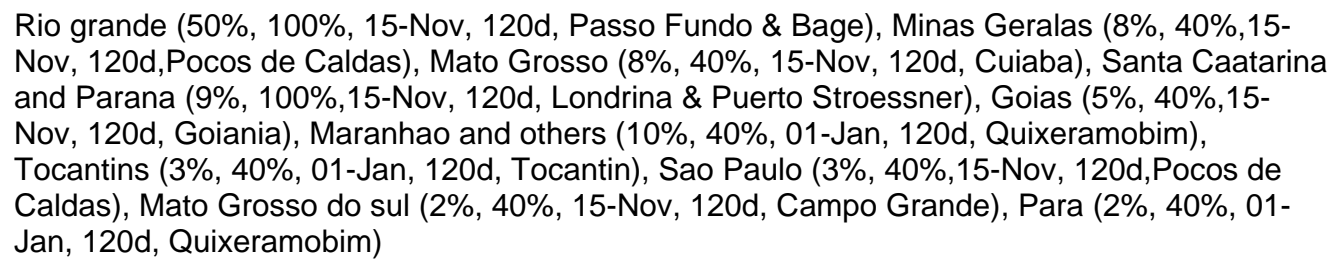 \\
\hline \multirow[t]{3}{*}{ China } & $\begin{array}{l}\text { Single crop: Hunan (1.44\%, 90\%, 1-May, 135d, Changsha), Sichuan (12\%, 90\%, 1-May, 135d, } \\
\text { Chungking), Jiangsu (9.12\%, 90\%,1-May, 135d, Hangzhou), Hubei }(4.32 \%, 90 \%, 1-M a y, 135 d \text {, } \\
\text { Changsha), Anhui (3.84\%, 90\%,1-May, 135d, Hangzhou), Fujian }(0.96 \%, 90 \%, 1-M a y, 135 d \text {, } \\
\text { Hangzhou), Yunnan (2.4\%, 90\%,1-May, 135d, Kunming), Liaoning 1.92\%, 90\%,1-May, 135d, } \\
\text { Shenyang), Guizhou (1.92\%, 90\%,1-May, 35d, Chungking), Heilongjiang (1.92\%, 90\%,1-May, } \\
\text { 135d, Harbin), Jilin (1.44\%, 90\%,1-May, 35d, Shenyang), Henan (1.44\%, 90\%,1-May, 135d, } \\
\text { Heze), Shanghai (0.96\%, 90\%,1-May, 135d, Hangzhou), Others (4.32\%, 90\%,1-May, 135d) }\end{array}$ \\
\hline & $\begin{array}{l}\text { Early double: Hunan }(5.46 \%, 90 \%, 1-M a r, 120 d \text {, Changsha), Hubei }(2.34 \%, 90 \% \text {, Changsha), } \\
\text { Guangdong (4.42\%, 90\%, Guangzhou), Jiangxi (3.64\%, 90\%, Changsha), Anhui }(1.3 \%, 90 \% \text {, } \\
\text { Hangzhou), Zhejiang (3.12\%, 90\%, Hangzhou), Guangxi (3.38\%, 90\%, Kunming), Fujian } \\
(1.56 \%, 90 \% \text {, Hangzhou), Others }(0.78 \%, 90 \%,)\end{array}$ \\
\hline & $\begin{array}{l}\text { Late double: Hunan }(6.24 \%, 90 \%, 1-A u g, 120 \mathrm{~d} \text {, Changsha), Hubei }(2.6 \%, 90 \% \text {, Changsha), } \\
\text { Guangdong (4.16\%, 90\%, 1-Aug, 120d, Guangzhou), Jiangxi (3.64\%,90\%,1-Aug, 120d, } \\
\text { Changsha), Anhui (1.3\%, 90\%, 1-Aug, 120d, Hangzhou), Zhejiang }(3.38 \%, 90 \%, 1-A u g, 120 d \text {, } \\
\text { Hangzhou), Guangxi }(2.34 \%, 90 \%, 1-A u g, 120 d \text {, Kunming), Fujian }(1.56 \%, 90 \%, 1-A u g, 120 d \text {, } \\
\text { Hangzhou), Others }(0.78 \%, 90 \%, 1-A u g, 120 d)\end{array}$ \\
\hline \multirow[t]{4}{*}{ India } & $\begin{array}{l}\text { Khariff: West Bengal (12.34\%, 195000ha, 01-Jun, 150d, Chandbali), Uttar Pradesh (16.43\%, } \\
3716000 h a, 15-J u n, 120 d, \text { Bareilly), Andhra Pradesh (8.70\%, 2503000ha, 01-Apr, 180d, } \\
\text { Begampet), Punjab (11.08\%, 2447000ha, 01-Jul, 120d, Amritsar), Tamil Nadu ( } 8.55 \% \text {, } \\
\text { 1764000ha, 01-May, 150d, Banglore), Bihar (9.40\%, 1942000ha, 15-Jun, 120d, Bareilly), } \\
\text { Orissa (6.73\%, 1375000ha, 01-Jun, 180d, Chandbali), Madhya Pradesh (7.20\%, 1282000ha, } \\
\text { 15-Jul, 150d, Pendra), Assam (4.10\%, 296000ha, 15-Mar, 150d, Guahati), Karnataka (3.38\%, } \\
\text { 615000ha, 150d, Banglore), Haryana (3.42 \%, 1024000ha, 150days,-), Maharashtra (3.25\%, } \\
\text { 385000ha, 150d,-), Gujarat (1.37\%, 371000ha, 150d,-), Kerala (0.83\%, 139000ha, 150d,-), } \\
\text { Jammu \& Kashmir (0.69\%, 239000ha, 150d,-), Tripura (0.55\%, 150d,-), Manipur (0.50\%, } \\
\text { 73000ha, 150d,-), Rajasthan (0.29\%, 63000ha, 150d,-), Nagaland (0.28\%, 65000ha,150d,-), } \\
\text { Meghalaya (0.21\%, 45000ha, 150d,-), Goa (0.20\%, 14000ha, 150d,-), Arunachal Pradesh } \\
\text { (0.17\%, 34000ha, 150d,-), Himachal Pradesh (0.16\%, 51000ha, 150d,-), Mizoram (0.14\%, } \\
\text { 4000ha, 150d,-), Sikkim (0.03\%, 16000ha, 150d,-). }\end{array}$ \\
\hline & $\begin{array}{l}\text { Note: Rainfed area in Khariff season in'000ha: West Bengal 4413, Uttar Pradesh 2104, Andhra } \\
\text { Pradesh 172, Punjab 22, Tamil Nadu 164, Bihar 3005, Orissa 2845, Madhya Pradesh 4139, } \\
\text { Assam 1980, Karnataka 452, Haryana 4, Maharashtra 1071, Gujarat 282, Kerala 165, Jammu } \\
\text { \& Kashmir 26, Tripura 202, Manipur 88, Rajasthan 115, Nagaland 81, Meghalaya 60, Goa 43, } \\
\text { Arunachal Pradesh 85, Himachal, Pradesh } 32 \text { Mizoram 57. Total rainfed area = 21606000ha }\end{array}$ \\
\hline & $\begin{array}{l}\text { Rabi: West Bengal (36.43\%, 1386000ha, 01-Dec, 150d, Chandbali), Uttar Pradesh }(0.12 \% \text {, } \\
6000 h a, 01-D e c, 150 d, \text { Bareilly), Andhra Pradesh (32.15\%, 1232000ha, 01-Jan, 150d, } \\
\text { Begampet), Tamil Nadu (9.20\%, 318000ha, 01-Nov, 150d, Banglore), Bihar (2.24\%, 128000ha, } \\
\text { 01-Nov, 150d, Bareilly), Orissa (5.19\%, 295000ha, 01-Jan, 150d, Chandbali), Assam (3.92\%, } \\
\text { 231000ha, 01-Jan, 150d, Guahati), Karnataka (8.21\%, 341000ha, 15-Jan, 150d, Banglore), } \\
\text { Maharashtra (0.55\%, 33000ha,-), Kerala (1.18\%, 59000ha,-), Tripura (0.81\%, 55000ha,-), } \\
\text { Mizoram (0.01\%, } 1000 \text { ha,-). }\end{array}$ \\
\hline & Note: Rabi crop is $100 \%$ irrigated in India. Total area under Rabi crop $=4085000$ ha \\
\hline
\end{tabular}




\begin{tabular}{|c|c|}
\hline Country & $\begin{array}{l}\text { Crop season, major rice harvesting regions, share to the national production, irrigated area in } \\
\% \text { or ha, crop planting date, crop length in days and relevant climate stations }\end{array}$ \\
\hline \multirow[t]{2}{*}{ Indonesia } & $\begin{array}{l}\text { Main crop: Java (41.3\%,60\%,, 15-Nov, 120d, Jakarta and Semarang), S.Sulawesi }(8.1 \%, 60 \% \text {, } \\
\text { 01-Jun, 120d, Manado), N.Sumatra (10.5\%, 60\%, 01-Aug, 120d, Medan), S.Sumatra (8.4\%, } \\
60 \%, 15-N o v, 20 d \text {, Palemban), Kalimanthan (5.0\%, 60\%,15-Nov, 120d, Banjamarsin), Bali and } \\
\text { Nusa (6.0\%, 60\%,15-Nov, 120d, Bali (Denpasa) and Nusa (Kupang)) }\end{array}$ \\
\hline & $\begin{array}{l}\text { Second crop: Java (17.7\%, 100\%, 15-May, 120d, Jakarta and Semarang), S.Sulawesi } \\
\text { (0.9\%,100\%, 01-Nov, 120d, Manado), N.Sumatra (1.1\%,100\%,01-Apr, 120d,Medan), } \\
\text { S.Sumatra (1.1\%,100\%,15-Jun, 120d, Palemban) }\end{array}$ \\
\hline Japan & 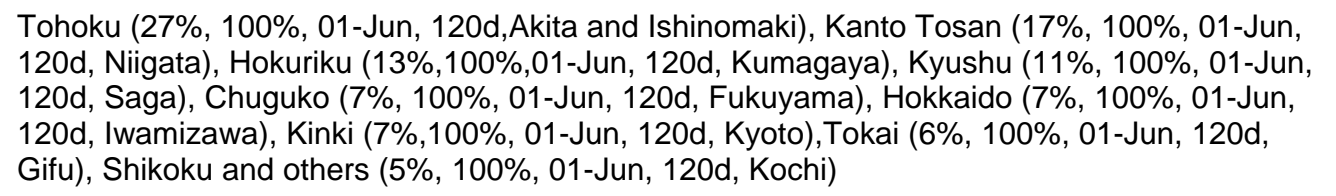 \\
\hline Korea, R. & $\begin{array}{l}\text { Inchon (33.33\%, 75\%, 01-Jun, 120d, Inchon), Taegu (33.33\%, 75\%, 01-Jun, 120d, Taegu), } \\
\text { Mok-poh (33.33\%, 75\%, 01-Jun, 120d, Mok-poh) }\end{array}$ \\
\hline Myanmar & $\begin{array}{l}\text { Irrawadi (23.15\%, 15.00\%, 01-Jun, 150d, Bassein),Pegu (15.23\%, 15.00\%, 01-Jun, 150d, } \\
\text { Pyinmana), Rangoon (8.60\%, 15.00\%,01-Jun, 150d, Rangoon), Sagaing }(7.88 \%, 15.00 \%, 1- \\
\text { Jun, 150d, Monywa), Arakan }(5.74 \%, 15.00 \%, 01-J u n, 150 d, \text { Sittwe), Shan }(6.12 \%, 15.00 \% \text {, } \\
\text { 01-Jun, 150d, Mandalay), Mon (4.61\%, 15.00\%, 01-Jun, 150d, Moulmein), Mandalay } \\
\text { (4.29\%,15.00\%,01-Jun, 150d, Mandalay),Karen \& others }(9.38 \%, 15.00 \%, 01-J u n, 150 d, \\
\text { Molumein), all other regions growing } 2^{\text {nd }} \text { crop }(15.00 \%, 100.00 \%, 01-J u n, 150 d, \text { Rangoon) }\end{array}$ \\
\hline Pakistan & $\begin{array}{l}\text { Punjab (43\%, 100\%, 01-Jun, 120d, Lahore), Sind (46\%, 100\%, 01-Jun, 120d, } \\
\text { Hyderabad/Karachi), Baluchistan (8\%, 100\%, 01-Jun, 120d, Hyderabad/Dadu), North West } \\
\text { Frontier Province }(3 \%, 100 \%, 01-J u n, 120 d \text {, Peshawar) }\end{array}$ \\
\hline Philippines & $\begin{array}{l}\text { Central Luzon, Southern Tagalog and Ilocos (35\%, 77\%, 01-Jun, 120d,Manila Airport), Cagyan } \\
\text { Valley and Cordillero AR (15\%, -\%, 01-Jun, 120d, Aparri),Western Vsyas and Central Visyas } \\
\text { (9\%, - } \%, 15-\text { Nov, 120d, Ilolo), Western Mindano and Central Mindano (12\%, 100\%, 15-Nov, } \\
\text { 120d, Dipolog), Northern Mindano and Southern Mindano (23\%, 100\%, 15-Nov, 120d, } \\
\text { Hinatuan), Bicol (4\%, -\%, 01-Jun, 120d, LegaspiEastern Visyas (2\%, - } \%, 15-N o v, 120 d, \\
\text { Massin) }\end{array}$ \\
\hline \multirow[t]{2}{*}{ Thailand } & $\begin{array}{l}\text { Main crop Northern }(23.2 \%, 23 \%, 01-J u n, 120 d, \text { ChiangM ai and NakhonS awan), Central } \\
(19.2 \%, 23 \%, 01-J u l, 120 d, \text { KrungT hep (Bangkok)),North East }(33.6 \%, 23 \%, 15-J u n, 120 d, \text {,Udon } \\
\text { Thani and Ubon Ratchathani),South (4\%,23\%,15-Oct, 120d,Ba nD on) }\end{array}$ \\
\hline & $\begin{array}{l}2^{\text {nd }} \mathrm{crop}: \text { Northern }(5 \%, 100 \%, 15-F e b, 120 d \text {, Chiang Mai and Nakhon Sawan), Central }(12.8 \% \text {, } \\
100 \%, 15-F e b, 120 d, \text { KrungT hep (Bangkok)), North East }(1.8 \%, 100 \%, 15-F e b, 120 d, \text { Udon } \\
\text { Thani and Ubon Ratchathani), South }(0.4 \%, 100 \%, 15-F e b, 120 d, \text { BanD on) }\end{array}$ \\
\hline USA & $\begin{array}{l}\text { Arkansas (43.3\%, 100\%, 01-May, 120d, Memphis), California (13.7\%, 100\%, 01-Jun, } 120 \mathrm{~d} \text {, } \\
\text { Sacramento and Frenso), Louisiana (18.8\%, 100\%, 01-May, 120d, Lafayette),Texas (12.4\%, } \\
100 \%, 01-\text { May, 120d,Victoria), Mississippi (8.6\%, 100\%, 01-May, 120d, Memphis), Missiouri } \\
(3.1 \%, 100 \%, 01-\text { May, 120d, Memphis) }\end{array}$ \\
\hline \multirow[t]{3}{*}{ Viet Nam } & $\begin{array}{l}\text { Winter crop North }(16.4 \%, 85 \%, 01-D e c, 105 d \text {, Hanoi), Central }(6.8 \%, 0 \%, 01-D e c, 120 d \text {, } \\
\text { QuiNhon), South (16.8\%, 60\%, 01-Jan, 120d, Ho Chi Minh (Saigon) }\end{array}$ \\
\hline & $\begin{array}{l}\text { Main crop North }(11.47 \%, 85 \%, 15-J u n, 105 d \text {, Hanoi), Central (8.14\%, 0\%, 15-Jun, 120d, } \\
\text { QuiNhon), South }(17.39 \%, 60 \%, 01-J u l, 105 d \text {, Ho Chi Minh (Saigon)) }\end{array}$ \\
\hline & $\begin{array}{l}\text { Autumn crop North (7.13\%, 85\%, 01-May, 105d, Hanoi), Central (5.06\%, 0\%, 01-May, 120d, } \\
\text { QuiNhon), South (10.81\%, 60\%, 01-May, 105d, Ho Chi Minh (Saigon)) }\end{array}$ \\
\hline \multicolumn{2}{|c|}{$\begin{array}{l}\text { The } K_{c} \text { values for the initial, mid and end crop development stages are taken as } 1.05,1.2 \text { and } 0.6 \text { respectively. } \\
\text { The } K_{c} \text { for the end period in China is taken equal to } 0.90 \text {. For India, the crop water requirement is calculated } \\
\text { only for the top } 10 \text {-states contributing to } 85 \% \text { of national production during Kharif season and } 91 \% \text { during } \\
\text { Rabi season. For the remaining regions the national average values for each season are taken. Source: } \\
\text { irrigation percentage of Khariff rice is from Directorate of Rice Development (2001). All other data were } \\
\text { compiled from USDA (1994) and various other online national statistical data sources. }\end{array}$} \\
\hline
\end{tabular}


Appendix B: Water footprint of national rice production. Period 2000-04.

\begin{tabular}{|c|c|c|c|c|c|c|c|c|}
\hline & \multirow{2}{*}{$\begin{array}{r}\text { Area* } \\
\text { ha }\end{array}$} & \multirow{2}{*}{$\begin{array}{l}\text { Yield* } \\
\text { ton/ha }\end{array}$} & \multirow{2}{*}{$\begin{array}{r}\text { Production* } \\
\text { ton/yr }\end{array}$} & \multicolumn{3}{|c|}{ Water footprint of production $\left(\mathrm{Mm}^{3} / \mathrm{yr}\right)$} & \multirow[b]{2}{*}{ Total } & \multirow{2}{*}{$\begin{array}{r}\text { Percolation } \\
\left(\mathrm{Mm}^{3} / \mathrm{yr}\right)\end{array}$} \\
\hline & & & & Green & Blue & Grey & & \\
\hline China & $28,670,030$ & 6.2 & $177,657,605$ & 65,241 & 86,460 & 20,786 & 172,486 & 139,518 \\
\hline India & $43,057,460$ & 2.9 & $126,503,280$ & 136,258 & 104,544 & 14,683 & 255,486 & 177,427 \\
\hline Indonesia & $11,642,899$ & 4.5 & $52,014,913$ & 30,309 & 25,323 & 6,113 & 61,744 & 48,213 \\
\hline Bangladesh & $10,641,271$ & 3.5 & $37,217,379$ & 20,415 & 21,463 & 3,831 & 45,708 & 41,985 \\
\hline Viet Nam & $7,512,160$ & 4.5 & $33,960,560$ & 10,455 & 6,888 & 4,319 & 21,663 & 23,661 \\
\hline Thailand & $10,038,180$ & 2.7 & $26,800,046$ & 25,247 & 14,980 & 3,112 & 43,339 & 33,591 \\
\hline Myanmar & $6,431,364$ & 3.5 & $22,581,828$ & 19,111 & 8,538 & 1,125 & 28,774 & 24,918 \\
\hline Philippines & $4,056,577$ & 3.3 & $13,322,327$ & 11,246 & 5,633 & 1,034 & 17,914 & 15,491 \\
\hline Brazil & $3,371,562$ & 3.3 & $11,068,502$ & 8,753 & 7,411 & 674 & 16,838 & 14,120 \\
\hline Japan & $1,706,000$ & 6.4 & $10,989,200$ & 3,744 & 4,408 & 665 & 8,818 & 8,317 \\
\hline USA & $1,285,671$ & 7.4 & $9,520,015$ & 2,161 & 7,951 & 964 & 11,076 & 6,262 \\
\hline Pakistan & $2,339,200$ & 3.0 & $6,910,650$ & 2,909 & 16,340 & 611 & 19,859 & 11,345 \\
\hline Korea, R & $1,045,173$ & 6.5 & $6,808,450$ & 2,423 & 2,644 & 575 & 5,641 & 4,320 \\
\hline Egypt & 630,353 & 9.5 & $5,972,257$ & 3,774 & 3,487 & 653 & 7,913 & 6,126 \\
\hline Nepal & $1,545,156$ & 2.7 & $4,220,395$ & 2,667 & 2,464 & 461 & 5,592 & 4,329 \\
\hline Cambodia & $2,045,837$ & 2.0 & $4,165,772$ & 2,632 & 2,432 & 455 & 5,520 & 4,273 \\
\hline Nigeria & $2,211,800$ & 1.4 & $3,085,600$ & 1,950 & 1,802 & 337 & 4,088 & 3,165 \\
\hline Sri Lanka & 809,552 & 3.5 & $2,822,732$ & 1,784 & 1,648 & 308 & 3,740 & 2,896 \\
\hline Madagascar & $1,219,074$ & 2.2 & $2,715,380$ & 1,716 & 1,585 & 297 & 3,598 & 2,785 \\
\hline Colombia & 499,532 & 5.1 & $2,579,150$ & 1,630 & 1,506 & 282 & 3,417 & 2,646 \\
\hline Iran & 577,372 & 4.2 & $2,464,653$ & 1,557 & 1,439 & 269 & 3,266 & 2,528 \\
\hline Laos & 746,177 & 3.2 & $2,371,400$ & 1,498 & 1,385 & 259 & 3,142 & 2,433 \\
\hline Malaysia & 680,660 & 3.2 & $2,190,829$ & 1,384 & 1,279 & 239 & 2,903 & 2,247 \\
\hline
\end{tabular}




\begin{tabular}{|c|c|c|c|c|c|c|c|c|}
\hline & \multirow{2}{*}{$\begin{array}{r}\text { Area* }^{*} \\
\text { ha }\end{array}$} & \multirow{2}{*}{$\begin{array}{l}\text { Yield* } \\
\text { ton/ha }\end{array}$} & \multirow{2}{*}{$\begin{array}{r}\text { Production* } \\
\text { ton/yr }\end{array}$} & \multicolumn{3}{|c|}{ Water footprint of production $\left(\mathrm{Mm}^{3} / \mathrm{yr}\right)$} & \multirow[b]{2}{*}{ Total } & \multirow{2}{*}{$\begin{array}{r}\text { Percolation } \\
\left(\mathrm{Mm}^{3} / \mathrm{yr}\right)\end{array}$} \\
\hline & & & & Green & Blue & Grey & & \\
\hline Korea, DPR & 571,371 & 3.7 & $2,110,040$ & 1,333 & 1,232 & 231 & 2,796 & 2,164 \\
\hline Peru & 301,409 & 6.6 & $2,003,010$ & 1,266 & 1,170 & 219 & 2,654 & 2,055 \\
\hline Ecuador & 367,290 & 3.8 & $1,419,705$ & 897 & 829 & 155 & 1,881 & 1,456 \\
\hline Italy & 221,009 & 6.1 & $1,359,921$ & 859 & 794 & 149 & 1,802 & 1,395 \\
\hline Guinea & 649,437 & 1.7 & $1,123,543$ & 710 & 656 & 123 & 1,489 & 1,153 \\
\hline Tanzania & 498,186 & 1.7 & 861,572 & 544 & 503 & 94 & 1,142 & 884 \\
\hline Argentina & 153,400 & 5.6 & 852,764 & 539 & 498 & 93 & 1,130 & 875 \\
\hline Spain & 117,248 & 7.3 & 852,050 & 538 & 497 & 93 & 1,129 & 874 \\
\hline Mali & 407,607 & 2.0 & 808,799 & 511 & 472 & 88 & 1,072 & 830 \\
\hline Venezuela & 152,577 & 4.9 & 751,797 & 475 & 439 & 82 & 996 & 771 \\
\hline Russian Federation & 141,600 & 3.5 & 498,952 & 315 & 291 & 55 & 661 & 512 \\
\hline Guyana & 118,627 & 4.1 & 487,027 & 308 & 284 & 53 & 645 & 500 \\
\hline Turkey & 62,400 & 6.2 & 386,400 & 244 & 226 & 42 & 512 & 396 \\
\hline Sierra Leone & 376,643 & 1.0 & 381,767 & 241 & 223 & 42 & 506 & 392 \\
\hline Afghanistan & 145,200 & 2.4 & 357,400 & 226 & 209 & 39 & 474 & 367 \\
\hline Bolivia & 145,134 & 2.3 & 329,117 & 208 & 192 & 36 & 436 & 338 \\
\hline Congo, DR & 426,004 & 0.8 & 321,633 & 203 & 188 & 35 & 426 & 330 \\
\hline Nicaragua & 87,129 & 3.2 & 277,059 & 175 & 162 & 30 & 367 & 284 \\
\hline Mexico & 62,032 & 4.4 & 271,416 & 171 & 158 & 30 & 360 & 278 \\
\hline Panama & 119,921 & 2.2 & 264,672 & 167 & 155 & 29 & 351 & 272 \\
\hline
\end{tabular}




\begin{tabular}{|c|c|c|c|c|c|c|c|c|}
\hline & \multirow{2}{*}{$\begin{array}{r}\text { Area* }^{*} \\
\text { ha }\end{array}$} & \multirow{2}{*}{$\begin{array}{l}\text { Yield* } \\
\text { ton/ha } \\
\end{array}$} & \multirow{2}{*}{$\begin{array}{r}\text { Production* }^{*} \\
\text { ton/yr }\end{array}$} & \multicolumn{3}{|c|}{ Water footprint of production $\left(\mathrm{Mm}^{3} / \mathrm{yr}\right)$} & \multirow[b]{2}{*}{ Total } & \multirow{2}{*}{$\begin{array}{r}\text { Percolation } \\
\left(\mathrm{Mm}^{3} / \mathrm{yr}\right)\end{array}$} \\
\hline & & & & Green & Blue & Grey & & \\
\hline Ghana & 122,088 & 2.1 & 256,783 & 162 & 150 & 28 & 340 & 263 \\
\hline Kazakhstan & 73,367 & 3.2 & 232,256 & 147 & 136 & 25 & 308 & 238 \\
\hline Costa Rica & 57,875 & 3.6 & 210,747 & 133 & 123 & 23 & 279 & 216 \\
\hline Senegal & 83,761 & 2.4 & 203,045 & 128 & 119 & 22 & 269 & 208 \\
\hline Uzbekistan & 84,562 & 2.2 & 182,526 & 115 & 107 & 20 & 242 & 187 \\
\hline Iraq & 83,500 & 2.1 & 155,600 & 98 & 91 & 17 & 206 & 160 \\
\hline Mozambique & 173,892 & 0.9 & 153,901 & 97 & 90 & 17 & 204 & 158 \\
\hline Portugal & 25,051 & 5.8 & 146,301 & 92 & 85 & 16 & 194 & 150 \\
\hline Chile & 27,086 & 5.0 & 136,072 & 86 & 79 & 15 & 180 & 140 \\
\hline Liberia & 126,700 & 1.0 & 129,680 & 82 & 76 & 14 & 172 & 133 \\
\hline Paraguay & 28,252 & 3.9 & 109,490 & 69 & 64 & 12 & 145 & 112 \\
\hline France & 19,348 & 5.6 & 109,166 & 69 & 64 & 12 & 145 & 112 \\
\hline Burkina Faso & 48,549 & 2.0 & 94,411 & 60 & 55 & 10 & 125 & 97 \\
\hline Guinea-Bissau & 68,314 & 1.3 & 91,315 & 58 & 53 & 10 & 121 & 94 \\
\hline Ukraine & 21,330 & 3.7 & 79,680 & 50 & 47 & 9 & 106 & 82 \\
\hline Malawi & 49,332 & 1.6 & 78,937 & 50 & 46 & 9 & 105 & 81 \\
\hline Mauritania & 17,450 & 4.4 & 75,390 & 48 & 44 & 8 & 100 & 77 \\
\hline Turkmenistan & 47,800 & 1.6 & 73,160 & 46 & 43 & 8 & 97 & 75 \\
\hline Niger & 23,132 & 3.0 & 70,376 & 44 & 41 & 8 & 93 & 72 \\
\hline Togo & 31,482 & 2.1 & 64,832 & 41 & 38 & 7 & 86 & 67 \\
\hline
\end{tabular}




\begin{tabular}{|c|c|c|c|c|c|c|c|c|}
\hline & \multirow{2}{*}{$\begin{array}{r}\text { Area* }^{*} \\
\text { ha }\end{array}$} & \multirow{2}{*}{$\begin{array}{l}\text { Yield* } \\
\text { ton/ha } \\
\end{array}$} & \multirow{2}{*}{$\begin{array}{r}\text { Production* }^{*} \\
\text { ton/yr }\end{array}$} & \multicolumn{3}{|c|}{ Water footprint of production $\left(\mathrm{Mm}^{3} / \mathrm{yr}\right)$} & \multirow[b]{2}{*}{ Total } & \multirow{2}{*}{$\begin{array}{r}\text { Percolation } \\
\left(\mathrm{Mm}^{3} / \mathrm{yr}\right)\end{array}$} \\
\hline & & & & Green & Blue & Grey & & \\
\hline Burundi & 18,840 & 3.2 & 60,207 & 38 & 35 & 7 & 80 & 62 \\
\hline Benin & 25,550 & 2.3 & 57,838 & 37 & 34 & 6 & 77 & 59 \\
\hline Timor-Leste & 34,710 & 1.8 & 57,087 & 36 & 33 & 6 & 76 & 59 \\
\hline Tajikistan & 17,154 & 3.3 & 56,563 & 36 & 33 & 6 & 75 & 58 \\
\hline Cameroon & 32,168 & 1.9 & 52,993 & 33 & 31 & 6 & 70 & 54 \\
\hline Guatemala & 14,956 & 2.6 & 39,557 & 25 & 23 & 4 & 52 & 41 \\
\hline El Salvador & 5,325 & 6.2 & 32,611 & 21 & 19 & 4 & 43 & 33 \\
\hline Gambia & 13,080 & 2.1 & 28,050 & 18 & 16 & 3 & 37 & 29 \\
\hline Morocco & 5,460 & 5.1 & 27,542 & 17 & 16 & 3 & 36 & 28 \\
\hline Central Afr. Rep. & 14,500 & 1.9 & 27,480 & 17 & 16 & 3 & 36 & 28 \\
\hline Kyrgyzstan & 6,126 & 3.0 & 18,609 & 12 & 11 & 2 & 25 & 19 \\
\hline Comoros & 14,000 & 1.2 & 17,000 & 11 & 10 & 2 & 23 & 17 \\
\hline Azerbaijan & 3,545 & 4.6 & 16,664 & 11 & 10 & 2 & 22 & 17 \\
\hline Sudan & 6,388 & 2.3 & 15,750 & 10 & 9 & 2 & 21 & 16 \\
\hline Honduras & 4,620 & 3.2 & 15,272 & 10 & 9 & 2 & 20 & 16 \\
\hline Zambia & 11,113 & 1.3 & 14,354 & 9 & 8 & 2 & 19 & 15 \\
\hline Fiji & 6,055 & 2.3 & 14,099 & 9 & 8 & 2 & 19 & 14 \\
\hline Ethiopia & 7,593 & 1.8 & 13,882 & 9 & 8 & 2 & 18 & 14 \\
\hline Macedonia & 2,627 & 4.8 & 12,582 & 8 & 7 & 1 & 17 & 13 \\
\hline Belize & 4,018 & 2.9 & 11,367 & 7 & 7 & 1 & 15 & 12 \\
\hline
\end{tabular}




\begin{tabular}{|c|c|c|c|c|c|c|c|c|}
\hline & \multirow{2}{*}{$\begin{array}{l}\text { Area* }^{*} \\
\text { ha }\end{array}$} & \multirow{2}{*}{$\begin{array}{l}\text { Yield* } \\
\text { ton/ha }\end{array}$} & \multirow{2}{*}{$\begin{array}{r}\text { Production* } \\
\text { ton/yr }\end{array}$} & \multicolumn{3}{|c|}{ Water footprint of production $\left(\mathrm{Mm}^{3} / \mathrm{yr}\right)$} & \multirow[b]{2}{*}{ Total } & \multirow{2}{*}{$\begin{array}{r}\text { Percolation } \\
\left(\mathrm{Mm}^{3} / \mathrm{yr}\right)\end{array}$} \\
\hline & & & & Green & Blue & Grey & & \\
\hline Hungary & 2,608 & 3.8 & 9,904 & 6 & 6 & 1 & 13 & 10 \\
\hline Somalia & 1,604 & 5.9 & 9,600 & 6 & 6 & 1 & 13 & 10 \\
\hline Angola & 6,196 & 1.3 & 7,378 & 5 & 4 & 1 & 10 & 8 \\
\hline Solomon Islands & 1,300 & 3.9 & 5,100 & 3 & 3 & 1 & 7 & 5 \\
\hline Trinidad \& Tbg. & 1,154 & 2.9 & 3,368 & 2.13 & 1.97 & 0.37 & 4.46 & 3.45 \\
\hline South Africa & 1,380 & 2.3 & 3,160 & 2.00 & 1.85 & 0.35 & 4.19 & 3.24 \\
\hline Romania & 889 & 2.3 & 2,183 & 1.38 & 1.27 & 0.24 & 2.89 & 2.24 \\
\hline Congo & 1,959 & 0.7 & 1,299 & 0.82 & 0.76 & 0.14 & 1.72 & 1.33 \\
\hline Gabon & 500 & 2.0 & 1,000 & 0.63 & 0.58 & 0.11 & 1.33 & 1.03 \\
\hline Papua New Guinea & 390 & 2.0 & 780 & 0.49 & 0.46 & 0.09 & 1.03 & 0.80 \\
\hline Zimbabwe & 266 & 2.3 & 620 & 0.39 & 0.36 & 0.07 & 0.82 & 0.64 \\
\hline Brunei Darussalam & 579 & 0.7 & 438 & 0.28 & 0.26 & 0.05 & 0.58 & 0.45 \\
\hline Algeria & 200 & 1.5 & 300 & 0.19 & 0.18 & 0.03 & 0.40 & 0.31 \\
\hline Swaziland & 50 & 3.4 & 170 & 0.11 & 0.10 & 0.02 & 0.23 & 0.17 \\
\hline Micronesia & 80 & 1.1 & 90 & 0.06 & 0.05 & 0.01 & 0.12 & 0.09 \\
\hline Réunion & 40 & 2.0 & 80 & 0.05 & 0.05 & 0.01 & 0.11 & 0.08 \\
\hline Jamaica & 14 & 1.1 & 16 & 0.01 & 0.01 & 0.00 & 0.02 & 0.02 \\
\hline Total & $150,666,851$ & 4.49 ** & $591,751,209$ & 373,907 & 345,512 & 64,655 & 784,073 & 607,019 \\
\hline
\end{tabular}

* Source: FAO (2009).

** Weighted average, calculated based on production per country. 
Appendix C. Water footprint of national rice consumption. Period 2000-04.

\begin{tabular}{|c|c|c|c|c|c|c|c|c|c|c|c|c|}
\hline & \multicolumn{4}{|c|}{ Internal water footprint $\left(\mathrm{Mm}^{3} / \mathrm{yr}\right)$} & \multicolumn{4}{|c|}{ External water footprint $\left(\mathrm{Mm}^{3} / \mathrm{yr}\right)$} & \multicolumn{4}{|c|}{ Total water footprint $\left(\mathrm{Mm}^{3} / \mathrm{yr}\right)^{\star}$} \\
\hline & Green & Blue & Grey & Total & Green & Blue & Grey & Total & Green & Blue & Grey & Total \\
\hline India & 133,493 & 102,423 & 14,385 & 250,301 & 1 & 3 & 0 & 4 & 133,494 & 102,425 & 14,385 & 250,305 \\
\hline China & 64,754 & 85,812 & 20,630 & 171,195 & 400 & 238 & 50 & 688 & 65,154 & 86,050 & 20,680 & 171,884 \\
\hline Indonesia & 30,301 & 25,316 & 6,111 & 61,727 & 797 & 689 & 151 & 1,637 & 31,097 & 26,005 & 6,262 & 63,364 \\
\hline Bangladesh & 20,414 & 21,462 & 3,831 & 45,707 & 146 & 112 & 16 & 273 & 20,560 & 21,574 & 3,846 & 45,980 \\
\hline Thailand & 19,639 & 11,653 & 2,421 & 33,713 & 1 & 1 & 0 & 2 & 19,640 & 11,654 & 2,421 & 33,714 \\
\hline Myanmar & 18,989 & 8,483 & 1,118 & 28,591 & - & - & - & - & 18,989 & 8,483 & 1,118 & 28,591 \\
\hline Viet nam & 9,860 & 6,496 & 4,074 & 20,430 & - & - & - & - & 9,860 & 6,496 & 4,074 & 20,430 \\
\hline Philippines & 11,246 & 5,633 & 1,034 & 17,914 & 490 & 386 & 103 & 979 & 11,736 & 6,020 & 1,137 & 18,893 \\
\hline Brazil & 8,735 & 7,396 & 673 & 16,804 & 451 & 474 & 84 & 1,008 & 9,186 & 7,869 & 757 & 17,812 \\
\hline Pakistan & 2,480 & 13,935 & 521 & 16,936 & - & - & - & - & 2,480 & 13,935 & 521 & 16,936 \\
\hline Japan & 3,724 & 4,386 & 662 & 8,772 & 360 & 537 & 86 & 983 & 4,084 & 4,923 & 748 & 9,755 \\
\hline USA & 1,598 & 5,554 & 679 & 7,831 & 326 & 225 & 41 & 591 & 1,924 & 5,779 & 719 & 8,422 \\
\hline Egypt & 3,467 & 3,203 & 599 & 7,269 & - & - & - & - & 3,467 & 3,203 & 599 & 7,269 \\
\hline Nigeria & 1,949 & 1,801 & 337 & 4,088 & 1,528 & 1,204 & 211 & 2,943 & 3,478 & 3,005 & 548 & 7,031 \\
\hline Korea rep. & 2,409 & 2,628 & 572 & 5,609 & 82 & 103 & 21 & 205 & 2,491 & 2,732 & 592 & 5,814 \\
\hline Nepal & 2,667 & 2,464 & 461 & 5,592 & 15 & 14 & 2 & 31 & 2,682 & 2,478 & 463 & 5,623 \\
\hline Cambodia & 2,628 & 2,428 & 454 & 5,511 & 46 & 31 & 6 & 83 & 2,674 & 2,459 & 461 & 5,594 \\
\hline Iran & 1,552 & 1,434 & 268 & 3,254 & 676 & 726 & 98 & 1,500 & 2,227 & 2,160 & 367 & 4,754 \\
\hline Madagascar & 1,715 & 1,585 & 297 & 3,597 & 114 & 280 & 21 & 414 & 1,829 & 1,865 & 318 & 4,012 \\
\hline Sri lanka & 1,782 & 1,647 & 308 & 3,737 & 80 & 124 & 10 & 214 & 1,862 & 1,771 & 318 & 3,951 \\
\hline Malaysia & 1,366 & 1,262 & 236 & 2,865 & 417 & 366 & 70 & 852 & 1,783 & 1,628 & 306 & 3,717 \\
\hline Colombia & 1,629 & 1,506 & 282 & 3,417 & 73 & 65 & 12 & 150 & 1,703 & 1,570 & 294 & 3,567 \\
\hline Laos & 1,498 & 1,385 & 259 & 3,142 & - & - & - & - & 1,498 & 1,385 & 259 & 3,142 \\
\hline
\end{tabular}




\begin{tabular}{|c|c|c|c|c|c|c|c|c|c|c|c|c|}
\hline & \multicolumn{4}{|c|}{ Internal water footprint $\left(\mathrm{Mm}^{3} / \mathrm{yr}\right)$} & \multicolumn{4}{|c|}{ External water footprint $\left(\mathrm{Mm}^{3} / \mathrm{yr}\right)$} & \multicolumn{4}{|c|}{ Total water footprint $\left(\mathrm{Mm}^{3} / \mathrm{yr}\right)^{*}$} \\
\hline & Green & Blue & Grey & Total & Green & Blue & Grey & Total & Green & Blue & Grey & Total \\
\hline Peru & 1,266 & 1,170 & 219 & 2,654 & 38 & 42 & 7 & 87 & 1,304 & 1,212 & 226 & 2,741 \\
\hline Ecuador & 863 & 797 & 149 & 1,809 & 1 & 1 & 0 & 3 & 864 & 798 & 149 & 1,812 \\
\hline Guinea & 710 & 656 & 123 & 1,489 & 90 & 112 & 20 & 223 & 800 & 768 & 143 & 1,711 \\
\hline Senegal & 128 & 118 & 22 & 269 & 756 & 482 & 107 & 1,344 & 884 & 600 & 129 & 1,613 \\
\hline Saudi arabia & - & - & - & - & 650 & 694 & 82 & 1,426 & 650 & 694 & 82 & 1,426 \\
\hline Tanzania & 541 & 500 & 94 & 1,135 & 90 & 95 & 21 & 207 & 631 & 595 & 115 & 1,341 \\
\hline South africa & 2 & 2 & 0 & 4 & 701 & 509 & 88 & 1,298 & 703 & 511 & 89 & 1,302 \\
\hline Mexico & 171 & 158 & 30 & 359 & 160 & 579 & 70 & 809 & 331 & 737 & 100 & 1,168 \\
\hline Russian fed & 304 & 282 & 53 & 639 & 231 & 224 & 58 & 513 & 535 & 505 & 111 & 1,152 \\
\hline Mali & 511 & 472 & 88 & 1,072 & 19 & 15 & 4 & 38 & 530 & 488 & 92 & 1,110 \\
\hline Turkey & 244 & 225 & 42 & 511 & 172 & 263 & 42 & 477 & 416 & 488 & 84 & 988 \\
\hline Venezuela & 456 & 421 & 79 & 956 & 4 & 15 & 2 & 21 & 460 & 437 & 81 & 977 \\
\hline Cuba & 385 & 356 & 67 & 808 & 72 & 71 & 26 & 169 & 457 & 428 & 92 & 977 \\
\hline Italy & 403 & 380 & 69 & 853 & 39 & 44 & 6 & 89 & 442 & 424 & 75 & 941 \\
\hline Cote divoire & 408 & 377 & 71 & 856 & - & - & - & - & 408 & 377 & 71 & 856 \\
\hline Australia & 366 & 339 & 62 & 767 & 41 & 40 & 5 & 87 & 407 & 379 & 68 & 854 \\
\hline Dominican $\mathrm{R}$ & 403 & 372 & 70 & 845 & 3 & 3 & 1 & 6 & 406 & 375 & 70 & 851 \\
\hline UK & - & - & - & - & 331 & 423 & 55 & 808 & 331 & 423 & 55 & 808 \\
\hline Spain & 321 & 301 & 56 & 678 & 52 & 57 & 9 & 118 & 373 & 358 & 65 & 796 \\
\hline France & 57 & 53 & 10 & 120 & 306 & 302 & 49 & 658 & 364 & 356 & 59 & 778 \\
\hline Ghana & 162 & 149 & 28 & 339 & 213 & 185 & 37 & 435 & 375 & 334 & 65 & 774 \\
\hline Argentina & 358 & 331 & 62 & 750 & 8 & 7 & 1 & 16 & 365 & 338 & 63 & 766 \\
\hline Hong kong & - & - & - & - & 367 & 235 & 48 & 651 & 367 & 235 & 48 & 651 \\
\hline Singapore & - & - & - & - & 346 & 219 & 49 & 614 & 346 & 219 & 49 & 614 \\
\hline Kenya & 29 & 27 & 5 & 62 & 98 & 349 & 20 & 467 & 127 & 376 & 25 & 529 \\
\hline
\end{tabular}




\begin{tabular}{|c|c|c|c|c|c|c|c|c|c|c|c|c|}
\hline & \multicolumn{4}{|c|}{ Internal water footprint $\left(\mathrm{Mm}^{3} / \mathrm{yr}\right)$} & \multicolumn{4}{|c|}{ External water footprint $\left(\mathrm{Mm}^{3} / \mathrm{yr}\right)$} & \multicolumn{4}{|c|}{ Total water footprint $\left(\mathrm{Mm}^{3} / \mathrm{yr}\right)^{*}$} \\
\hline & Green & Blue & Grey & Total & Green & Blue & Grey & Total & Green & Blue & Grey & Total \\
\hline Uruguay & 248 & 229 & 43 & 519 & 0 & 0 & 0 & 1 & 248 & 229 & 43 & 520 \\
\hline Afghanistan & 224 & 207 & 39 & 470 & - & - & - & - & 224 & 207 & 39 & 470 \\
\hline Bolivia & 207 & 191 & 36 & 434 & 5 & 5 & 1 & 11 & 212 & 196 & 37 & 445 \\
\hline Nicaragua & 174 & 161 & 30 & 366 & 15 & 42 & 5 & 62 & 189 & 203 & 36 & 428 \\
\hline Congo DR & 203 & 188 & 35 & 426 & - & - & - & - & 203 & 188 & 35 & 426 \\
\hline Guyana & 193 & 178 & 33 & 405 & 0 & 0 & 0 & 0 & 193 & 178 & 33 & 405 \\
\hline Costa rica & 130 & 121 & 23 & 273 & 26 & 94 & 11 & 131 & 156 & 215 & 34 & 405 \\
\hline Mozambique & 95 & 89 & 16 & 200 & 56 & 127 & 9 & 192 & 151 & 215 & 26 & 392 \\
\hline Canada & - & - & - & - & 118 & 219 & 28 & 365 & 118 & 219 & 28 & 365 \\
\hline Panama & 160 & 148 & 28 & 335 & 3 & 10 & 1 & 14 & 163 & 158 & 29 & 349 \\
\hline Germany & - & - & - & - & 140 & 178 & 26 & 344 & 140 & 178 & 26 & 344 \\
\hline Portugal & 89 & 82 & 15 & 186 & 75 & 69 & 13 & 156 & 163 & 150 & 28 & 342 \\
\hline Oman & - & - & - & - & 83 & 241 & 14 & 339 & 83 & 241 & 14 & 339 \\
\hline Kazakstan & 130 & 120 & 22 & 272 & 1 & 2 & 0 & 4 & 131 & 122 & 23 & 276 \\
\hline Niger & 44 & 41 & 8 & 93 & 69 & 94 & 13 & 176 & 113 & 135 & 21 & 269 \\
\hline Burkina faso & 60 & 55 & 10 & 125 & 67 & 56 & 10 & 133 & 127 & 111 & 20 & 258 \\
\hline Belgium & - & - & - & - & 108 & 117 & 18 & 243 & 108 & 117 & 18 & 243 \\
\hline Uzbekistan & 115 & 106 & 20 & 241 & - & - & - & - & 115 & 106 & 20 & 241 \\
\hline Uganda & 75 & 69 & 13 & 157 & 24 & 53 & 7 & 83 & 99 & 122 & 20 & 241 \\
\hline Chile & 85 & 79 & 15 & 179 & 30 & 24 & 4 & 58 & 115 & 103 & 19 & 237 \\
\hline Iraq & 92 & 85 & 16 & 192 & - & - & - & - & 92 & 85 & 16 & 192 \\
\hline Jordan & - & - & - & - & 79 & 91 & 15 & 184 & 79 & 91 & 15 & 184 \\
\hline Mauritius & - & - & - & - & 51 & 119 & 8 & 179 & 51 & 119 & 8 & 179 \\
\hline Suriname & 85 & 78 & 15 & 178 & - & - & - & - & 85 & 78 & 15 & 178 \\
\hline Liberia & 82 & 75 & 14 & 171 & - & - & - & - & 82 & 75 & 14 & 171 \\
\hline
\end{tabular}




\begin{tabular}{|c|c|c|c|c|c|c|c|c|c|c|c|c|}
\hline & \multicolumn{4}{|c|}{ Internal water footprint $\left(\mathrm{Mm}^{3} / \mathrm{yr}\right)$} & \multicolumn{4}{|c|}{ External water footprint $\left(\mathrm{Mm}^{3} / \mathrm{yr}\right)$} & \multicolumn{4}{|c|}{ Total water footprint $\left(\mathrm{Mm}^{3} / \mathrm{yr}\right)^{\star}$} \\
\hline & Green & Blue & Grey & Total & Green & Blue & Grey & Total & Green & Blue & Grey & Total \\
\hline Poland & - & - & - & - & 69 & 86 & 14 & 170 & 69 & 86 & 14 & 170 \\
\hline Benin & 36 & 33 & 6 & 76 & 47 & 39 & 7 & 93 & 83 & 73 & 13 & 169 \\
\hline Togo & 39 & 36 & 7 & 82 & 37 & 38 & 7 & 81 & 76 & 74 & 13 & 164 \\
\hline Haiti & 72 & 67 & 12 & 151 & - & - & - & - & 72 & 67 & 12 & 151 \\
\hline Ukraine & 50 & 46 & 9 & 105 & 24 & 19 & 4 & 46 & 74 & 65 & 13 & 151 \\
\hline Qatar & - & - & - & - & 31 & 103 & 5 & 139 & 31 & 103 & 5 & 139 \\
\hline Kuwait & - & - & - & - & 57 & 74 & 7 & 138 & 57 & 74 & 7 & 138 \\
\hline Gambia & 18 & 16 & 3 & 37 & 50 & 42 & 8 & 99 & 68 & 58 & 11 & 137 \\
\hline Romania & 1 & 1 & 0 & 3 & 61 & 60 & 12 & 133 & 62 & 62 & 12 & 136 \\
\hline Paraguay & 63 & 58 & 11 & 131 & 2 & 1 & 0 & 3 & 64 & 59 & 11 & 134 \\
\hline Gabon & 1 & 1 & 0 & 1 & 63 & 38 & 8 & 109 & 64 & 38 & 9 & 111 \\
\hline Taiwan (poc) & - & - & - & - & 40 & 63 & 8 & 110 & 40 & 63 & 8 & 110 \\
\hline Turkmenistan & 46 & 43 & 8 & 97 & 3 & 3 & 1 & 7 & 50 & 46 & 9 & 104 \\
\hline Hungary & 6 & 6 & 1 & 13 & 36 & 34 & 6 & 76 & 42 & 40 & 7 & 89 \\
\hline Algeria & 0 & 0 & 0 & 0 & 41 & 37 & 10 & 87 & 41 & 37 & 10 & 87 \\
\hline Netherlands & - & - & - & - & 20 & 63 & 4 & 87 & 20 & 63 & 4 & 87 \\
\hline Sweden & - & - & - & - & 40 & 38 & 6 & 85 & 40 & 38 & 6 & 85 \\
\hline Czech rep & - & - & - & - & 37 & 38 & 7 & 83 & 37 & 38 & 7 & 83 \\
\hline Burundi & 38 & 35 & 7 & 80 & 0 & 0 & 0 & 0 & 38 & 35 & 7 & 80 \\
\hline
\end{tabular}




\begin{tabular}{|c|c|c|c|c|c|c|c|c|c|c|c|c|}
\hline & \multicolumn{4}{|c|}{ Internal water footprint $\left(\mathrm{Mm}^{3} / \mathrm{yr}\right)$} & \multicolumn{4}{|c|}{ External water footprint $\left(\mathrm{Mm}^{3} / \mathrm{yr}\right)$} & \multicolumn{4}{|c|}{ Total water footprint $\left(\mathrm{Mm}^{3} / \mathrm{yr}\right)^{\star}$} \\
\hline & Green & Blue & Grey & Total & Green & Blue & Grey & Total & Green & Blue & Grey & Total \\
\hline Bahrain & & - & - & - & 19 & 57 & 3 & 80 & 19 & 57 & 3 & 80 \\
\hline Israel & - & - & - & - & 37 & 28 & 6 & 70 & 37 & 28 & 6 & 70 \\
\hline Cameroon & 33 & 31 & 6 & 70 & - & - & - & - & 33 & 31 & 6 & 70 \\
\hline Jamaica & 0 & 0 & 0 & 0 & 27 & 35 & 6 & 68 & 27 & 35 & 6 & 68 \\
\hline Tajikistan & 31 & 29 & 5 & 66 & - & - & - & - & 31 & 29 & 5 & 66 \\
\hline Lebanon & - & - & - & - & 30 & 29 & 5 & 65 & 30 & 29 & 5 & 65 \\
\hline New zealand & - & - & - & - & 29 & 29 & 4 & 62 & 29 & 29 & 4 & 62 \\
\hline Bhutan & 28 & 26 & 5 & 59 & - & - & - & - & 28 & 26 & 5 & 59 \\
\hline Bulgaria & 13 & 12 & 2 & 27 & 13 & 15 & 3 & 31 & 26 & 26 & 5 & 58 \\
\hline Honduras & 9 & 9 & 2 & 19 & 7 & 26 & 3 & 37 & 16 & 35 & 5 & 56 \\
\hline Belarus & - & - & - & - & 24 & 26 & 4 & 54 & 24 & 26 & 4 & 54 \\
\hline Azerbaijan & 10 & 10 & 2 & 22 & 14 & 15 & 2 & 32 & 25 & 25 & 4 & 54 \\
\hline Fiji & 9 & 8 & 2 & 19 & 19 & 13 & 3 & 35 & 28 & 21 & 4 & 54 \\
\hline Slovakia & - & - & - & - & 24 & 25 & 4 & 53 & 24 & 25 & 4 & 53 \\
\hline Rwanda & 15 & 14 & 3 & 32 & 6 & 11 & 1 & 18 & 21 & 25 & 4 & 50 \\
\hline Macau & - & - & - & - & 27 & 17 & 4 & 47 & 27 & 17 & 4 & 47 \\
\hline Denmark & - & - & - & - & 22 & 20 & 4 & 46 & 22 & 20 & 4 & 46 \\
\hline Austria & - & - & - & - & 22 & 20 & 4 & 46 & 22 & 20 & 4 & 46 \\
\hline Trinidad tbg & 2 & 2 & 0 & 4 & 16 & 19 & 3 & 37 & 18 & 20 & 3 & 41 \\
\hline Cent.af.rep & 17 & 16 & 3 & 36 & 1 & 2 & 0 & 3 & 19 & 18 & 3 & 40 \\
\hline Finland & - & - & - & - & 19 & 17 & 3 & 40 & 19 & 17 & 3 & 40 \\
\hline Morocco & 17 & 16 & 3 & 36 & 1 & 1 & 0 & 3 & 19 & 17 & 3 & 39 \\
\hline Ethiopia & 9 & 8 & 2 & 18 & 8 & 9 & 1 & 18 & 17 & 17 & 3 & 36 \\
\hline Norway & - & - & - & - & 17 & 15 & 2 & 34 & 17 & 15 & 2 & 34 \\
\hline Sudan & 10 & 9 & 2 & 21 & 6 & 5 & 1 & 12 & 16 & 15 & 3 & 33 \\
\hline
\end{tabular}




\begin{tabular}{|c|c|c|c|c|c|c|c|c|c|c|c|c|}
\hline & \multicolumn{4}{|c|}{ Internal water footprint $\left(\mathrm{Mm}^{3} / \mathrm{yr}\right)$} & \multicolumn{4}{|c|}{ External water footprint $\left(\mathrm{Mm}^{3} / \mathrm{yr}\right)$} & \multicolumn{4}{|c|}{ Total water footprint $\left(\mathrm{Mm}^{3} / \mathrm{yr}\right)^{*}$} \\
\hline & Green & Blue & Grey & Total & Green & Blue & Grey & Total & Green & Blue & Grey & Total \\
\hline Zambia & 9 & 8 & 2 & 19 & 7 & 6 & 1 & 14 & 16 & 14 & 3 & 33 \\
\hline Maldives & - & - & - & - & 16 & 15 & 2 & 33 & 16 & 15 & 2 & 33 \\
\hline Albania & - & - & - & - & 14 & 14 & 3 & 31 & 14 & 14 & 3 & 31 \\
\hline Kyrgyzstan & 12 & 11 & 2 & 25 & 1 & 1 & 0 & 3 & 13 & 12 & 2 & 27 \\
\hline Tunisia & - & - & - & - & 15 & 9 & 2 & 26 & 15 & 9 & 2 & 26 \\
\hline Brunei dar. & 0 & 0 & 0 & 1 & 11 & 7 & 1 & 20 & 12 & 7 & 1 & 20 \\
\hline Lithuania & - & - & - & - & 9 & 9 & 1 & 20 & 9 & 9 & 1 & 20 \\
\hline Ireland & - & - & - & - & 8 & 9 & 2 & 18 & 8 & 9 & 2 & 18 \\
\hline Armenia & - & - & - & - & 7 & 8 & 1 & 17 & 7 & 8 & 1 & 17 \\
\hline Macedonia & 7 & 7 & 1 & 16 & 0 & 0 & 0 & 1 & 8 & 7 & 1 & 16 \\
\hline Fr.polynesia & - & - & - & - & 8 & 7 & 1 & 16 & 8 & 7 & 1 & 16 \\
\hline Croatia & - & - & - & - & 8 & 7 & 1 & 16 & 8 & 7 & 1 & 16 \\
\hline Moldova rep. & - & - & - & - & 6 & 8 & 1 & 15 & 6 & 8 & 1 & 15 \\
\hline Belize & 7 & 7 & 1 & 15 & 0 & 0 & 0 & 0 & 7 & 7 & 1 & 15 \\
\hline Zimbabwe & 0 & 0 & 0 & 1 & 7 & 6 & 1 & 14 & 8 & 6 & 1 & 15 \\
\hline Others & 5 & 5 & 1 & 11 & 57 & 74 & 13 & 143 & 62 & 79 & 13 & 154 \\
\hline Grand total & 360,336 & 331,511 & 62,360 & 754,208 & 13,570 & 14,000 & 2,295 & 29,865 & 373,907 & 345,512 & 64,655 & 784,073 \\
\hline
\end{tabular}

* Note: this refers to the total water footprint of national rice consumption. It does not include water losses as a result of percolation and left over soil moisture in the rice fields. 
Appendix D. Virtual water fluxes related to the international trade in rice products. Period 2000-04.

\begin{tabular}{|c|c|c|c|c|c|c|c|c|c|c|c|c|}
\hline \multirow[b]{2}{*}{ Country } & \multicolumn{4}{|c|}{ Gross virtual water import $\left(\mathrm{Mm}^{3} / \mathrm{yr}\right)$} & \multicolumn{4}{|c|}{ Gross virtual water export $\left(\mathrm{Mm}^{3} / \mathrm{yr}\right)$} & \multicolumn{4}{|c|}{ Net virtual water import $\left(\mathrm{Mm}^{3} / \mathrm{yr}\right)$} \\
\hline & Green & Blue & Grey & Total & Green & Blue & Grey & Total & Green & Blue & Grey & Total \\
\hline Afghanistan & & & & & 1.8 & 1.6 & 0.3 & 3.7 & -1.8 & -1.6 & -0.3 & -3.7 \\
\hline Albania & 14.2 & 14.0 & 2.8 & 30.9 & & & & & 14.2 & 14.0 & 2.8 & 30.9 \\
\hline Algeria & 40.9 & 36.6 & 9.6 & 87.1 & 0.0 & 0.0 & 0.0 & 0.0 & 40.9 & 36.6 & 9.6 & 87.1 \\
\hline Andorra & 0.3 & 0.3 & 0.0 & 0.6 & 0.2 & 0.1 & 0.0 & 0.3 & 0.1 & 0.1 & 0.0 & 0.3 \\
\hline Anguilla & 0.1 & 0.3 & 0.0 & 0.4 & & & & & 0.1 & 0.3 & 0.0 & 0.4 \\
\hline Antigua Barbados & 0.2 & 0.2 & 0.0 & 0.4 & & & & & 0.2 & 0.2 & 0.0 & 0.4 \\
\hline Argentina & 11.3 & 10.7 & 1.5 & 23.5 & 184.9 & 170.9 & 32.0 & 387.8 & -173.6 & -160.1 & -30.5 & -364.2 \\
\hline Armenia & 7.3 & 8.2 & 1.3 & 16.9 & & & & & 7.3 & 8.2 & 1.3 & 16.9 \\
\hline Aruba & & & & & 9.8 & 9.0 & 1.7 & 20.5 & -9.8 & -9.0 & -1.7 & -20.5 \\
\hline Australia & 70.4 & 68.0 & 9.4 & 147.7 & 285.7 & 264.0 & 49.4 & 599.2 & -215.3 & -196.0 & -40.0 & -451.4 \\
\hline Austria & 23.0 & 21.5 & 3.9 & 48.4 & 1.3 & 1.2 & 0.2 & 2.8 & 21.6 & 20.3 & 3.7 & 45.5 \\
\hline Azerbaijan & 14.5 & 15.3 & 2.2 & 32.0 & 0.2 & 0.2 & 0.0 & 0.4 & 14.3 & 15.1 & 2.2 & 31.6 \\
\hline Bahamas & 0.9 & 3.4 & 0.4 & 4.7 & 0.9 & 0.8 & 0.1 & 1.8 & 0.1 & 2.6 & 0.3 & 2.9 \\
\hline Bahrain & 19.6 & 57.7 & 3.1 & 80.3 & 0.3 & 0.2 & 0.0 & 0.5 & 19.3 & 57.4 & 3.0 & 79.8 \\
\hline Bangladesh & 145.6 & 111.8 & 15.7 & 273.1 & 0.5 & 0.6 & 0.1 & 1.2 & 145.0 & 111.2 & 15.6 & 271.8 \\
\hline Barbados & 2.1 & 6.1 & 0.8 & 9.0 & 0.0 & 0.0 & 0.0 & 0.0 & 2.1 & 6.1 & 0.8 & 8.9 \\
\hline Belarus & 24.2 & 25.8 & 4.2 & 54.2 & & & & & 24.2 & 25.8 & 4.2 & 54.2 \\
\hline Belgium & 188.5 & 191.5 & 32.4 & 412.3 & 80.9 & 74.8 & 14.0 & 169.7 & 107.6 & 116.7 & 18.4 & 242.6 \\
\hline Belize & 0.0 & 0.1 & 0.0 & 0.1 & 0.2 & 0.1 & 0.0 & 0.3 & -0.1 & 0.0 & 0.0 & -0.2 \\
\hline Benin & 47.0 & 39.4 & 6.9 & 93.3 & 0.6 & 0.6 & 0.1 & 1.3 & 46.3 & 38.8 & 6.8 & 91.9 \\
\hline Bhutan & & & & & 0.0 & 0.0 & 0.0 & 0.0 & 0.0 & 0.0 & 0.0 & 0.0 \\
\hline Bolivia & 5.3 & 5.1 & 0.9 & 11.3 & 1.2 & 1.1 & 0.2 & 2.6 & 4.0 & 4.0 & 0.7 & 8.7 \\
\hline Bosnia Herzg & 1.6 & 1.6 & 0.3 & 3.5 & & & & & 1.6 & 1.6 & 0.3 & 3.5 \\
\hline
\end{tabular}




\begin{tabular}{|c|c|c|c|c|c|c|c|c|c|c|c|c|}
\hline \multirow[b]{2}{*}{ Country } & \multicolumn{4}{|c|}{ Gross virtual water import ( $\left.\mathrm{Mm}^{3} / \mathrm{yr}\right)$} & \multicolumn{4}{|c|}{ Gross virtual water export ( $\left.\mathrm{Mm}^{3} / \mathrm{yr}\right)$} & \multicolumn{4}{|c|}{ Net virtual water import $\left(\mathrm{Mm}^{3} / \mathrm{yr}\right)$} \\
\hline & Green & Blue & Grey & Total & Green & Blue & Grey & Total & Green & Blue & Grey & Total \\
\hline Botswana & 4.4 & 4.1 & 0.8 & 9.3 & & & & & 4.4 & 4.1 & 0.8 & 9.3 \\
\hline Br.Virgin Is & & & & & 1.0 & 0.9 & 0.2 & 2.1 & -1.0 & -0.9 & -0.2 & -2.1 \\
\hline Brazil & 451.7 & 474.5 & 84.0 & 1010.2 & 18.8 & 15.9 & 1.4 & 36.1 & 432.9 & 458.6 & 82.6 & 974.1 \\
\hline Brunei & 11.6 & 7.1 & 1.5 & 20.2 & 0.2 & 0.2 & 0.0 & 0.4 & 11.4 & 7.0 & 1.4 & 19.8 \\
\hline Bulgaria & 13.9 & 15.2 & 3.1 & 32.2 & 1.2 & 1.1 & 0.2 & 2.5 & 12.7 & 14.1 & 2.9 & 29.7 \\
\hline Burkina Faso & 67.5 & 55.7 & 10.2 & 133.4 & 0.3 & 0.2 & 0.0 & 0.5 & 67.2 & 55.4 & 10.2 & 132.8 \\
\hline Burundi & 0.0 & 0.0 & 0.0 & 0.1 & & & & & 0.0 & 0.0 & 0.0 & 0.1 \\
\hline Cambodia & 46.1 & 30.8 & 6.1 & 83.0 & 4.2 & 3.9 & 0.7 & 8.8 & 41.9 & 26.9 & 5.4 & 74.1 \\
\hline Cameroon & & & & & 0.1 & 0.1 & 0.0 & 0.1 & -0.1 & -0.1 & 0.0 & -0.1 \\
\hline Canada & 122.3 & 223.6 & 29.0 & 374.9 & 4.5 & 4.2 & 0.8 & 9.5 & 117.8 & 219.4 & 28.2 & 365.4 \\
\hline Cape Verde & 5.1 & 3.5 & 1.5 & 10.1 & & & & & 5.1 & 3.5 & 1.5 & 10.1 \\
\hline Cayman Islds & & & & & 0.2 & 0.1 & 0.0 & 0.3 & -0.2 & -0.1 & 0.0 & -0.3 \\
\hline Cent.Afr. R. & 1.4 & 1.8 & 0.2 & 3.4 & & & & & 1.4 & 1.8 & 0.2 & 3.4 \\
\hline Chile & 30.2 & 24.0 & 4.5 & 58.6 & 1.0 & 0.9 & 0.2 & 2.1 & 29.2 & 23.1 & 4.3 & 56.5 \\
\hline China & 403.3 & 239.9 & 50.4 & 693.7 & 490.2 & 649.7 & 156.2 & 1296.1 & -87.0 & -409.8 & -105.7 & -602.5 \\
\hline Colombia & 73.5 & 64.7 & 12.1 & 150.3 & 0.3 & 0.3 & 0.1 & 0.6 & 73.2 & 64.4 & 12.0 & 149.7 \\
\hline Costa Rica & 26.4 & 95.6 & 11.6 & 133.6 & 3.9 & 3.6 & 0.7 & 8.2 & 22.5 & 91.9 & 10.9 & 125.3 \\
\hline Cote Divoire & & & & & 1.7 & 1.5 & 0.3 & 3.5 & -1.7 & -1.5 & -0.3 & -3.5 \\
\hline Croatia & 8.1 & 7.1 & 1.4 & 16.5 & 0.4 & 0.4 & 0.1 & 0.8 & 7.7 & 6.7 & 1.3 & 15.7 \\
\hline Cuba & 71.6 & 71.4 & 25.5 & 168.5 & 0.0 & 0.0 & 0.0 & 0.1 & 71.5 & 71.4 & 25.5 & 168.5 \\
\hline Cyprus & 3.9 & 3.8 & 0.6 & 8.3 & 11.4 & 10.5 & 2.0 & 23.8 & -7.4 & -6.7 & -1.3 & -15.5 \\
\hline Czech R. & 40.9 & 41.8 & 7.5 & 90.3 & 3.6 & 3.3 & 0.6 & 7.6 & 37.3 & 38.4 & 6.9 & 82.7 \\
\hline Denmark & 25.7 & 23.4 & 4.4 & 53.5 & 3.4 & 3.2 & 0.6 & 7.2 & 22.2 & 20.3 & 3.8 & 46.3 \\
\hline Djibouti & & & & & 1.9 & 1.8 & 0.3 & 4.1 & -1.9 & -1.8 & -0.3 & -4.1 \\
\hline Dominica & 0.8 & 0.7 & 0.1 & 1.6 & & & & & 0.8 & 0.7 & 0.1 & 1.6 \\
\hline
\end{tabular}




\begin{tabular}{|c|c|c|c|c|c|c|c|c|c|c|c|c|}
\hline \multirow[b]{2}{*}{ Country } & \multicolumn{4}{|c|}{ Gross virtual water import $\left(\mathrm{Mm}^{3} / \mathrm{yr}\right)$} & \multicolumn{4}{|c|}{ Gross virtual water export $\left(\mathrm{Mm}^{3} / \mathrm{yr}\right)$} & \multicolumn{4}{|c|}{ Net virtual water import $\left(\mathrm{Mm}^{3} / \mathrm{yr}\right)$} \\
\hline & Green & Blue & Grey & Total & Green & Blue & Grey & Total & Green & Blue & Grey & Total \\
\hline Dominican R. & 2.6 & 3.0 & 0.5 & 6.2 & 3.9 & 3.6 & 0.7 & 8.1 & -1.2 & -0.6 & -0.2 & -2.0 \\
\hline Ecuador & 1.3 & 1.2 & 0.2 & 2.7 & 34.3 & 31.7 & 5.9 & 72.0 & -33.0 & -30.5 & -5.7 & -69.3 \\
\hline Egypt & & & & & 307.0 & 283.7 & 53.1 & 643.9 & -307.0 & -283.7 & -53.1 & -643.9 \\
\hline El Salvador & 19.7 & 62.3 & 7.8 & 89.7 & 0.8 & 0.7 & 0.1 & 1.6 & 18.9 & 61.6 & 7.6 & 88.1 \\
\hline Eritrea & 0.5 & 0.5 & 0.1 & 1.1 & & & & & 0.5 & 0.5 & 0.1 & 1.1 \\
\hline Estonia & 2.3 & 3.7 & 0.4 & 6.4 & & & & & 2.3 & 3.7 & 0.4 & 6.4 \\
\hline Ethiopia & 8.0 & 9.0 & 1.2 & 18.2 & 0.1 & 0.1 & 0.0 & 0.2 & 7.9 & 8.9 & 1.1 & 18.0 \\
\hline Fiji & 19.5 & 12.8 & 2.6 & 34.9 & & & & & 19.5 & 12.8 & 2.6 & 34.9 \\
\hline Finland & 19.9 & 18.0 & 3.4 & 41.3 & 0.8 & 0.7 & 0.1 & 1.6 & 19.1 & 17.3 & 3.2 & 39.7 \\
\hline Fr.Polynesia & 7.8 & 6.7 & 1.3 & 15.8 & & & & & 7.8 & 6.7 & 1.3 & 15.8 \\
\hline France & 369.7 & 361.4 & 59.9 & 791.0 & 75.2 & 69.5 & 13.0 & 157.6 & 294.6 & 291.9 & 46.9 & 633.4 \\
\hline Gabon & 63.1 & 37.9 & 8.4 & 109.4 & 0.0 & 0.0 & 0.0 & 0.1 & 63.0 & 37.8 & 8.4 & 109.3 \\
\hline Gambia & 49.9 & 41.6 & 8.0 & 99.5 & 0.1 & 0.1 & 0.0 & 0.2 & 49.8 & 41.5 & 8.0 & 99.4 \\
\hline Georgia & 2.5 & 1.7 & 0.4 & 4.6 & & & & & 2.5 & 1.7 & 0.4 & 4.6 \\
\hline Germany & 205.0 & 238.4 & 37.7 & 481.0 & 65.2 & 60.2 & 11.3 & 136.7 & 139.8 & 178.1 & 26.4 & 344.4 \\
\hline Ghana & 214.2 & 186.0 & 37.0 & 437.2 & 1.6 & 1.4 & 0.3 & 3.3 & 212.6 & 184.5 & 36.7 & 433.9 \\
\hline Greece & 11.4 & 11.8 & 1.9 & 25.1 & 46.7 & 43.1 & 8.1 & 97.8 & -35.3 & -31.4 & -6.1 & -72.8 \\
\hline Grenada & 0.9 & 1.1 & 0.2 & 2.2 & & & & & 0.9 & 1.1 & 0.2 & 2.2 \\
\hline Guatemala & 16.2 & 52.7 & 6.5 & 75.5 & 0.6 & 0.5 & 0.1 & 1.2 & 15.6 & 52.2 & 6.4 & 74.2 \\
\hline Guinea & 90.1 & 112.2 & 20.4 & 222.7 & & & & & 90.1 & 112.2 & 20.4 & 222.7 \\
\hline Guyana & 0.1 & 0.1 & 0.0 & 0.1 & 114.6 & 105.9 & 19.8 & 240.4 & -114.6 & -105.9 & -19.8 & -240.3 \\
\hline Haiti & & & & & 0.1 & 0.1 & 0.0 & 0.2 & -0.1 & -0.1 & 0.0 & -0.2 \\
\hline Honduras & 7.7 & 27.3 & 3.3 & 38.4 & 1.4 & 1.3 & 0.2 & 3.0 & 6.3 & 26.0 & 3.1 & 35.4 \\
\hline Hong Kong & 368.5 & 236.9 & 48.8 & 654.2 & 1.3 & 1.8 & 0.4 & 3.5 & 367.1 & 235.2 & 48.4 & 650.7 \\
\hline Hungary & 36.1 & 34.3 & 6.2 & 76.6 & 0.1 & 0.1 & 0.0 & 0.2 & 36.0 & 34.3 & 6.1 & 76.4 \\
\hline
\end{tabular}




\begin{tabular}{|c|c|c|c|c|c|c|c|c|c|c|c|c|}
\hline \multirow[b]{2}{*}{ Country } & \multicolumn{4}{|c|}{ Gross virtual water import $\left(\mathrm{Mm}^{3} / \mathrm{yr}\right)$} & \multicolumn{4}{|c|}{ Gross virtual water export $\left(\mathrm{Mm}^{3} / \mathrm{yr}\right)$} & \multicolumn{4}{|c|}{ Net virtual water import $\left(\mathrm{Mm}^{3} / \mathrm{yr}\right)$} \\
\hline & Green & Blue & Grey & Total & Green & Blue & Grey & Total & Green & Blue & Grey & Total \\
\hline Iceland & 0.7 & 0.8 & 0.1 & 1.6 & 0.0 & 0.0 & 0.0 & 0.1 & 0.6 & 0.8 & 0.1 & 1.5 \\
\hline India & 1.3 & 2.7 & 0.4 & 4.4 & 2765.4 & 2121.7 & 298.0 & 5185.1 & -2764.0 & -2119.0 & -297.6 & -5180.7 \\
\hline Indonesia & 796.9 & 689.2 & 151.2 & 1637.3 & 8.6 & 7.2 & 1.7 & 17.5 & 788.3 & 682.0 & 149.5 & 1619.8 \\
\hline Iran & 678.0 & 729.0 & 98.8 & 1505.9 & 8.3 & 7.7 & 1.4 & 17.4 & 669.8 & 721.4 & 97.4 & 1488.5 \\
\hline Iraq & & & & & 6.8 & 6.3 & 1.2 & 14.2 & -6.8 & -6.3 & -1.2 & -14.2 \\
\hline Ireland & 10.4 & 10.8 & 1.9 & 23.1 & 2.3 & 2.1 & 0.4 & 4.7 & 8.1 & 8.7 & 1.5 & 18.4 \\
\hline Israel & 37.0 & 27.7 & 5.6 & 70.3 & 0.0 & 0.0 & 0.0 & 0.0 & 37.0 & 27.7 & 5.6 & 70.3 \\
\hline Italy & 82.5 & 91.7 & 12.8 & 187.1 & 499.6 & 461.7 & 86.4 & 1047.7 & -417.1 & -369.9 & -73.6 & -860.6 \\
\hline Jamaica & 27.3 & 35.2 & 5.7 & 68.2 & 0.0 & 0.0 & 0.0 & 0.0 & 27.3 & 35.2 & 5.7 & 68.2 \\
\hline Japan & 361.9 & 539.6 & 86.9 & 988.3 & 21.6 & 25.5 & 3.8 & 51.0 & 340.2 & 514.1 & 83.0 & 937.3 \\
\hline Jordan & 80.3 & 91.9 & 15.0 & 187.1 & 1.3 & 1.2 & 0.2 & 2.8 & 78.9 & 90.7 & 14.7 & 184.3 \\
\hline Kazakstan & 1.7 & 2.1 & 0.5 & 4.2 & 17.4 & 16.1 & 3.0 & 36.4 & -15.7 & -13.9 & -2.5 & -32.2 \\
\hline Kenya & 98.1 & 349.0 & 20.1 & 467.2 & 0.0 & 0.0 & 0.0 & 0.1 & 98.0 & 349.0 & 20.1 & 467.1 \\
\hline Korea Rep. & 82.1 & 103.7 & 20.8 & 206.6 & 14.5 & 15.8 & 3.4 & 33.7 & 67.7 & 87.9 & 17.3 & 173.0 \\
\hline Kuwait & 57.1 & 74.6 & 7.0 & 138.6 & 0.2 & 0.2 & 0.0 & 0.5 & 56.8 & 74.4 & 6.9 & 138.1 \\
\hline Kyrgyzstan & 1.0 & 1.4 & 0.3 & 2.7 & & & & & 1.0 & 1.4 & 0.3 & 2.7 \\
\hline Latvia & 4.9 & 5.8 & 0.9 & 11.6 & 3.1 & 2.9 & 0.5 & 6.5 & 1.8 & 2.9 & 0.3 & 5.1 \\
\hline Lebanon & 30.1 & 29.5 & 5.1 & 64.7 & 0.1 & 0.1 & 0.0 & 0.2 & 30.1 & 29.4 & 5.1 & 64.6 \\
\hline Liberia & & & & & 0.3 & 0.3 & 0.1 & 0.6 & -0.3 & -0.3 & -0.1 & -0.6 \\
\hline Lithuania & 9.2 & 9.6 & 1.4 & 20.3 & 0.3 & 0.3 & 0.1 & 0.6 & 8.9 & 9.4 & 1.4 & 19.6 \\
\hline Luxembourg & 1.1 & 1.0 & 0.2 & 2.3 & 0.0 & 0.0 & 0.0 & 0.1 & 1.1 & 1.0 & 0.2 & 2.2 \\
\hline Macau & 27.0 & 16.7 & 3.5 & 47.2 & & & & & 27.0 & 16.7 & 3.5 & 47.2 \\
\hline Macedonia & 0.4 & 0.4 & 0.1 & 0.9 & 0.5 & 0.5 & 0.1 & 1.1 & -0.1 & -0.1 & 0.0 & -0.2 \\
\hline Madagascar & 113.6 & 279.7 & 21.3 & 414.5 & 0.3 & 0.3 & 0.0 & 0.6 & 113.3 & 279.4 & 21.2 & 413.9 \\
\hline Malawi & 2.8 & 4.0 & 0.5 & 7.3 & 0.1 & 0.1 & 0.0 & 0.2 & 2.7 & 3.9 & 0.4 & 7.0 \\
\hline
\end{tabular}




\begin{tabular}{|c|c|c|c|c|c|c|c|c|c|c|c|c|}
\hline \multirow[b]{2}{*}{ Country } & \multicolumn{4}{|c|}{ Gross virtual water import ( $\left.\mathrm{Mm}^{3} / \mathrm{yr}\right)$} & \multicolumn{4}{|c|}{ Gross virtual water export $\left(\mathrm{Mm}^{3} / \mathrm{yr}\right)$} & \multicolumn{4}{|c|}{ Net virtual water import $\left(\mathrm{Mm}^{3} / \mathrm{yr}\right)$} \\
\hline & Green & Blue & Grey & Total & Green & Blue & Grey & Total & Green & Blue & Grey & Total \\
\hline Malaysia & 422.2 & 371.0 & 70.5 & 863.6 & 23.4 & 21.7 & 4.1 & 49.1 & 398.7 & 349.3 & 66.5 & 814.5 \\
\hline Maldives & 16.3 & 14.5 & 1.9 & 32.7 & & & & & 16.3 & 14.5 & 1.9 & 32.7 \\
\hline Mali & 19.3 & 15.5 & 3.6 & 38.4 & & & & & 19.3 & 15.5 & 3.6 & 38.4 \\
\hline Malta & 1.2 & 1.3 & 0.2 & 2.6 & & & & & 1.2 & 1.3 & 0.2 & 2.6 \\
\hline Mauritius & 51.3 & 119.3 & 8.3 & 178.8 & & & & & 51.3 & 119.3 & 8.3 & 178.8 \\
\hline Mexico & 160.1 & 579.5 & 70.5 & 810.0 & 0.6 & 0.6 & 0.1 & 1.3 & 159.4 & 578.9 & 70.4 & 808.7 \\
\hline Moldova Rep. & 5.8 & 7.7 & 1.4 & 14.9 & & & & & 5.8 & 7.7 & 1.4 & 14.9 \\
\hline Mongolia & 3.3 & 4.2 & 1.0 & 8.5 & 0.3 & 0.2 & 0.0 & 0.5 & 3.1 & 4.0 & 0.9 & 7.9 \\
\hline Montserrat & 0.0 & 0.1 & 0.0 & 0.2 & & & & & 0.0 & 0.1 & 0.0 & 0.2 \\
\hline Morocco & 1.1 & 1.4 & 0.2 & 2.7 & & & & & 1.1 & 1.4 & 0.2 & 2.7 \\
\hline Mozambique & 57.3 & 128.5 & 9.4 & 195.2 & 3.4 & 3.2 & 0.6 & 7.2 & 53.9 & 125.3 & 8.8 & 188.1 \\
\hline Myanmar & & & & & 121.5 & 54.3 & 7.2 & 182.9 & -121.5 & -54.3 & -7.2 & -182.9 \\
\hline N.Caledonia & 6.4 & 5.4 & 1.0 & 12.8 & & & & & 6.4 & 5.4 & 1.0 & 12.8 \\
\hline Namibia & 4.0 & 4.5 & 0.7 & 9.3 & & & & & 4.0 & 4.5 & 0.7 & 9.3 \\
\hline Nepal & 15.4 & 13.9 & 1.9 & 31.2 & 0.2 & 0.1 & 0.0 & 0.3 & 15.2 & 13.8 & 1.8 & 30.8 \\
\hline Neth.Antiles & & & & & 7.6 & 7.0 & 1.3 & 15.9 & -7.6 & -7.0 & -1.3 & -15.9 \\
\hline Netherlands & 154.2 & 187.0 & 27.0 & 368.3 & 133.9 & 123.8 & 23.2 & 280.9 & 20.3 & 63.2 & 3.9 & 87.4 \\
\hline New Zealand & 29.1 & 28.6 & 4.5 & 62.2 & 0.1 & 0.1 & 0.0 & 0.1 & 29.1 & 28.5 & 4.5 & 62.1 \\
\hline Nicaragua & 15.0 & 42.2 & 5.4 & 62.6 & 0.8 & 0.8 & 0.1 & 1.7 & 14.2 & 41.4 & 5.3 & 60.9 \\
\hline Niger & 69.0 & 93.9 & 13.1 & 175.9 & & & & & 69.0 & 93.9 & 13.1 & 175.9 \\
\hline Nigeria & 1528.5 & 1203.9 & 211.4 & 2943.8 & 0.4 & 0.3 & 0.1 & 0.8 & 1528.1 & 1203.6 & 211.3 & 2943.0 \\
\hline Norway & 18.7 & 16.3 & 2.6 & 37.6 & 1.9 & 1.8 & 0.3 & 4.1 & 16.7 & 14.5 & 2.3 & 33.5 \\
\hline Oman & 83.3 & 241.5 & 14.4 & 339.2 & 0.3 & 0.3 & 0.1 & 0.6 & 83.0 & 241.2 & 14.3 & 338.5 \\
\hline Pakistan & & & & & 428.1 & 2405.2 & 89.9 & 2923.2 & -428.1 & -2405.2 & -89.9 & -2923.2 \\
\hline Panama & 2.8 & 10.2 & 1.2 & 14.3 & 7.6 & 7.0 & 1.3 & 15.9 & -4.7 & 3.2 & -0.1 & -1.6 \\
\hline
\end{tabular}




\begin{tabular}{|c|c|c|c|c|c|c|c|c|c|c|c|c|}
\hline \multirow[b]{2}{*}{ Country } & \multicolumn{4}{|c|}{ Gross virtual water import $\left(\mathrm{Mm}^{3} / \mathrm{yr}\right)$} & \multicolumn{4}{|c|}{ Gross virtual water export $\left(\mathrm{Mm}^{3} / \mathrm{yr}\right)$} & \multicolumn{4}{|c|}{ Net virtual water import $\left(\mathrm{Mm}^{3} / \mathrm{yr}\right)$} \\
\hline & Green & Blue & Grey & Total & Green & Blue & Grey & Total & Green & Blue & Grey & Total \\
\hline Paraguay & 1.7 & 1.5 & 0.2 & 3.3 & 6.8 & 6.3 & 1.2 & 14.3 & -5.1 & -4.8 & -1.0 & -11.0 \\
\hline Peru & 38.0 & 42.2 & 7.3 & 87.5 & & & & & 38.0 & 42.2 & 7.3 & 87.5 \\
\hline Philippines & 489.8 & 386.4 & 103.0 & 979.2 & 0.1 & 0.1 & 0.0 & 0.2 & 489.7 & 386.3 & 103.0 & 979.0 \\
\hline Poland & 69.9 & 86.9 & 13.8 & 170.6 & 0.5 & 0.5 & 0.1 & 1.1 & 69.4 & 86.4 & 13.7 & 169.5 \\
\hline Portugal & 77.9 & 71.7 & 13.4 & 163.0 & 7.3 & 6.7 & 1.3 & 15.2 & 70.7 & 65.0 & 12.1 & 147.8 \\
\hline Russian Fed & 238.8 & 231.7 & 59.8 & 530.3 & 19.0 & 17.6 & 3.3 & 39.9 & 219.8 & 214.1 & 56.5 & 490.4 \\
\hline Rwanda & 5.7 & 11.0 & 1.3 & 18.0 & & & & & 5.7 & 11.0 & 1.3 & 18.0 \\
\hline S.Vincent-Gr & 2.8 & 7.5 & 1.0 & 11.2 & 2.5 & 2.3 & 0.4 & 5.3 & 0.3 & 5.2 & 0.5 & 5.9 \\
\hline Samoa & 1.3 & 1.7 & 0.4 & 3.4 & & & & & 1.3 & 1.7 & 0.4 & 3.4 \\
\hline Sao Tome Prn & 0.6 & 0.7 & 0.1 & 1.4 & & & & & 0.6 & 0.7 & 0.1 & 1.4 \\
\hline Singapore & 383.0 & 252.5 & 55.3 & 690.7 & 36.5 & 33.7 & 6.3 & 76.5 & 346.5 & 218.8 & 49.0 & 614.2 \\
\hline Slovakia & 24.0 & 24.9 & 4.5 & 53.4 & 0.1 & 0.1 & 0.0 & 0.3 & 23.8 & 24.8 & 4.5 & 53.1 \\
\hline Slovenia & 6.0 & 5.8 & 1.1 & 12.9 & 1.6 & 1.5 & 0.3 & 3.4 & 4.4 & 4.2 & 0.8 & 9.4 \\
\hline Somalia & & & & & 1.0 & 0.9 & 0.2 & 2.0 & -1.0 & -0.9 & -0.2 & -2.0 \\
\hline South Africa & 724.5 & 531.1 & 92.4 & 1347.9 & 23.7 & 21.9 & 4.1 & 49.8 & 700.8 & 509.1 & 88.3 & 1298.2 \\
\hline Spain & 87.0 & 94.4 & 15.8 & 197.2 & 252.7 & 233.5 & 43.7 & 529.9 & -165.7 & -139.1 & -27.9 & -332.6 \\
\hline Sri Lanka & 79.7 & 124.1 & 10.2 & 214.0 & 1.5 & 1.4 & 0.3 & 3.2 & 78.1 & 122.7 & 9.9 & 210.8 \\
\hline St.Kitts Nev & 0.3 & 1.0 & 0.1 & 1.4 & & & & & 0.3 & 1.0 & 0.1 & 1.4 \\
\hline St.Lucia & 2.0 & 2.0 & 0.4 & 4.4 & 0.0 & 0.0 & 0.0 & 0.0 & 2.0 & 2.0 & 0.4 & 4.3 \\
\hline
\end{tabular}




\begin{tabular}{|c|c|c|c|c|c|c|c|c|c|c|c|c|}
\hline \multirow[b]{2}{*}{ Country } & \multicolumn{4}{|c|}{ Gross virtual water import $\left(\mathrm{Mm}^{3} / \mathrm{yr}\right)$} & \multicolumn{4}{|c|}{ Gross virtual water export $\left(\mathrm{Mm}^{3} / \mathrm{yr}\right)$} & \multicolumn{4}{|c|}{ Net virtual water import $\left(\mathrm{Mm}^{3} / \mathrm{yr}\right)$} \\
\hline & Green & Blue & Grey & Total & Green & Blue & Grey & Total & Green & Blue & Grey & Total \\
\hline Sudan & 5.7 & 5.5 & 1.0 & 12.2 & & & & & 5.7 & 5.5 & 1.0 & 12.2 \\
\hline Suriname & & & & & 26.5 & 24.5 & 4.6 & 55.6 & -26.5 & -24.5 & -4.6 & -55.6 \\
\hline Swaziland & 6.1 & 5.7 & 1.1 & 12.9 & & & & & 6.1 & 5.7 & 1.1 & 12.9 \\
\hline Sweden & 41.3 & 38.9 & 6.3 & 86.6 & 0.8 & 0.8 & 0.1 & 1.7 & 40.5 & 38.2 & 6.2 & 84.9 \\
\hline Switz.Liecht & 72.7 & 65.8 & 10.5 & 149.1 & 15.6 & 14.4 & 2.7 & 32.7 & 57.2 & 51.4 & 7.8 & 116.4 \\
\hline Syria & 140.8 & 117.7 & 22.2 & 280.7 & 261.9 & 242.0 & 45.3 & 549.2 & -121.1 & -124.3 & -23.1 & -268.5 \\
\hline Taiwan (Poc) & 49.7 & 76.4 & 11.3 & 137.4 & 10.2 & 13.5 & 3.2 & 27.0 & 39.5 & 62.9 & 8.0 & 110.5 \\
\hline Tajikistan & & & & & 4.4 & 4.1 & 0.8 & 9.3 & -4.4 & -4.1 & -0.8 & -9.3 \\
\hline Tanzania & 90.9 & 96.0 & 21.0 & 207.9 & 3.9 & 3.6 & 0.7 & 8.1 & 87.0 & 92.4 & 20.4 & 199.8 \\
\hline Thailand & 0.8 & 1.1 & 0.2 & 2.1 & 5608.3 & 3327.6 & 691.2 & 9627.1 & -5607.5 & -3326.5 & -691.0 & -9625.0 \\
\hline Togo & 38.7 & 39.1 & 7.0 & 84.8 & 3.3 & 3.0 & 0.6 & 6.9 & 35.5 & 36.0 & 6.4 & 77.9 \\
\hline Tokelau & & & & & 0.7 & 0.6 & 0.1 & 1.4 & -0.7 & -0.6 & -0.1 & -1.4 \\
\hline Tonga & & & & & 0.1 & 0.1 & 0.0 & 0.2 & -0.1 & -0.1 & 0.0 & -0.2 \\
\hline Trinidad Tbg & 17.2 & 20.1 & 3.2 & 40.4 & 1.7 & 1.6 & 0.3 & 3.6 & 15.5 & 18.5 & 2.9 & 36.9 \\
\hline Tunisia & 14.9 & 9.2 & 1.9 & 25.9 & 0.0 & 0.0 & 0.0 & 0.0 & 14.9 & 9.1 & 1.9 & 25.9 \\
\hline Turkey & 172.4 & 263.5 & 41.6 & 477.5 & 0.8 & 0.8 & 0.1 & 1.7 & 171.6 & 262.8 & 41.4 & 475.8 \\
\hline Turkmenistan & 3.4 & 3.2 & 0.6 & 7.2 & 0.1 & 0.0 & 0.0 & 0.1 & 3.3 & 3.2 & 0.6 & 7.1 \\
\hline Turks Ca.Isl & 1.8 & 6.7 & 0.8 & 9.3 & 0.5 & 0.5 & 0.1 & 1.0 & 1.3 & 6.2 & 0.7 & 8.3 \\
\hline Uganda & 24.3 & 52.8 & 6.7 & 83.8 & 0.5 & 0.4 & 0.1 & 1.0 & 23.8 & 52.3 & 6.6 & 82.7 \\
\hline Ukraine & 23.6 & 19.0 & 4.0 & 46.6 & 0.4 & 0.4 & 0.1 & 0.9 & 23.2 & 18.6 & 3.9 & 45.7 \\
\hline Untd Arab Em & & & & & 139.2 & 128.6 & 24.1 & 291.9 & -139.2 & -128.6 & -24.1 & -291.9 \\
\hline UK & 392.0 & 479.6 & 65.3 & 936.8 & 61.3 & 56.6 & 10.6 & 128.5 & 330.7 & 423.0 & 54.7 & 808.4 \\
\hline Uruguay & 0.7 & 0.6 & 0.1 & 1.4 & 428.6 & 396.1 & 74.1 & 898.8 & -428.0 & -395.5 & -74.0 & -897.4 \\
\hline USA & 440.7 & 321.9 & 57.6 & 820.2 & 677.7 & 2493.8 & 302.4 & 3473.9 & -237.0 & -2171.8 & -244.8 & -2653.6 \\
\hline Uzbekistan & & & & & 0.3 & 0.3 & 0.0 & 0.6 & -0.3 & -0.3 & 0.0 & -0.6 \\
\hline
\end{tabular}




\begin{tabular}{|c|c|c|c|c|c|c|c|c|c|c|c|c|}
\hline \multirow[b]{2}{*}{ Country } & \multicolumn{4}{|c|}{ Gross virtual water import $\left(\mathrm{Mm}^{3} / \mathrm{yr}\right)$} & \multicolumn{4}{|c|}{ Gross virtual water export $\left(\mathrm{Mm}^{3} / \mathrm{yr}\right)$} & \multicolumn{4}{|c|}{ Net virtual water import $\left(\mathrm{Mm}^{3} / \mathrm{yr}\right)$} \\
\hline & Green & Blue & Grey & Total & Green & Blue & Grey & Total & Green & Blue & Grey & Total \\
\hline Venezuela & 4.3 & 15.9 & 1.9 & 22.1 & 19.7 & 18.2 & 3.4 & 41.2 & -15.3 & -2.3 & -1.5 & -19.1 \\
\hline Viet Nam & & & & & 595.2 & 392.1 & 245.9 & 1233.2 & -595.2 & -392.1 & -245.9 & -1233.2 \\
\hline Yemen & 70.6 & 61.7 & 9.2 & 141.6 & & & & & 70.6 & 61.7 & 9.2 & 141.6 \\
\hline Zambia & 6.9 & 6.1 & 1.1 & 14.1 & & & & & 6.9 & 6.1 & 1.1 & 14.1 \\
\hline Zimbabwe & 7.3 & 5.6 & 1.1 & 14.1 & 0.1 & 0.1 & 0.0 & 0.2 & 7.2 & 5.5 & 1.1 & 13.9 \\
\hline Others & 0.0 & 0.0 & 0.0 & 0.0 & 12.2 & 11.2 & 2.1 & 25.5 & -12.1 & -11.2 & -2.1 & -25.5 \\
\hline Total & 14081.2 & 14591.7 & 2379.0 & 31051.8 & 14069.0 & 14580.5 & 2376.9 & 31026.4 & & & & \\
\hline
\end{tabular}





\section{Value of Water Research Report Series}

Editorial board:

Arjen Y. Hoekstra - University of Twente, a.y.hoekstra@utwente.nl

Hubert H.G. Savenije - Delft University of Technology, h.h.g.savenije@tudelft.nl

Pieter van der Zaag - UNESCO-IHE Institute for Water Education, p.vanderzaag@unesco-ihe.org

1. Exploring methods to assess the value of water: A case study on the Zambezi basin.

A.K. Chapagain - February 2000

2. Water value flows: A case study on the Zambezi basin.

A.Y. Hoekstra, H.H.G. Savenije and A.K. Chapagain - March 2000

3. The water value-flow concept.

I.M. Seyam and A.Y. Hoekstra - December 2000

4. The value of irrigation water in Nyanyadzi smallholder irrigation scheme, Zimbabwe.

G.T. Pazvakawambwa and P. van der Zaag - January 2001

5. The economic valuation of water: Principles and methods

J.I. Agudelo - August 2001

6. The economic valuation of water for agriculture: A simple method applied to the eight Zambezi basin countries J.I. Agudelo and A.Y. Hoekstra - August 2001

7. The value of freshwater wetlands in the Zambezi basin

I.M. Seyam, A.Y. Hoekstra, G.S. Ngabirano and H.H.G. Savenije - August 2001

8. 'Demand management' and 'Water as an economic good': Paradigms with pitfalls H.H.G. Savenije and P. van der Zaag - October 2001

9. Why water is not an ordinary economic good H.H.G. Savenije - October 2001

10. Calculation methods to assess the value of upstream water flows and storage as a function of downstream benefits I.M. Seyam, A.Y. Hoekstra and H.H.G. Savenije - October 2001

11. Virtual water trade: A quantification of virtual water flows between nations in relation to international crop trade A.Y. Hoekstra and P.Q. Hung - September 2002

12. Virtual water trade: Proceedings of the international expert meeting on virtual water trade A.Y. Hoekstra (ed.) - February 2003

13. Virtual water flows between nations in relation to trade in livestock and livestock products A.K. Chapagain and A.Y. Hoekstra - July 2003

14. The water needed to have the Dutch drink coffee A.K. Chapagain and A.Y. Hoekstra - August 2003

15. The water needed to have the Dutch drink tea A.K. Chapagain and A.Y. Hoekstra - August 2003

16. Water footprints of nations, Volume 1: Main Report, Volume 2: Appendices A.K. Chapagain and A.Y. Hoekstra - November 2004

17. Saving water through global trade A.K. Chapagain, A.Y. Hoekstra and H.H.G. Savenije - September 2005

18. The water footprint of cotton consumption A.K. Chapagain, A.Y. Hoekstra, H.H.G. Savenije and R. Gautam - September 2005

19. Water as an economic good: the value of pricing and the failure of markets P. van der Zaag and H.H.G. Savenije - July 2006

20. The global dimension of water governance: Nine reasons for global arrangements in order to cope with local water problems A.Y. Hoekstra - July 2006

21. The water footprints of Morocco and the Netherlands A.Y. Hoekstra and A.K. Chapagain - July 2006

22. Water's vulnerable value in Africa P. van der Zaag - July 2006

23. Human appropriation of natural capital: Comparing ecological footprint and water footprint analysis A.Y. Hoekstra - July 2007

24. A river basin as a common-pool resource: A case study for the Jaguaribe basin in Brazil P.R. van Oel, M.S. Krol and A.Y. Hoekstra - July 2007

25. Strategic importance of green water in international crop trade M.M. Aldaya, A.Y. Hoekstra and J.A. Allan - March 2008 
26. Global water governance: Conceptual design of global institutional arrangements

M.P. Verkerk, A.Y. Hoekstra and P.W. Gerbens-Leenes - March 2008

27. Business water footprint accounting: A tool to assess how production of goods and services impact on freshwater resources worldwide

P.W. Gerbens-Leenes and A.Y. Hoekstra - March 2008

28. Water neutral: reducing and offsetting the impacts of water footprints

A.Y. Hoekstra - March 2008

29. Water footprint of bio-energy and other primary energy carriers

P.W. Gerbens-Leenes, A.Y. Hoekstra and Th.H. van der Meer - March 2008

30. Food consumption patterns and their effect on water requirement in China

J. Liu and H.H.G. Savenije - March 2008

31. Going against the flow: A critical analysis of virtual water trade in the context of India's National River Linking Programme

S. Verma, D.A. Kampman, P. van der Zaag and A.Y. Hoekstra - March 2008

32. The water footprint of India

D.A. Kampman, A.Y. Hoekstra and M.S. Krol - May 2008

33. The external water footprint of the Netherlands: Quantification and impact assessment

P.R. van Oel, M.M. Mekonnen and A.Y. Hoekstra - May 2008

34. The water footprint of bio-energy: Global water use for bio-ethanol, bio-diesel, heat and electricity

P.W. Gerbens-Leenes, A.Y. Hoekstra and Th.H. van der Meer - August 2008

35. Water footprint analysis for the Guadiana river basin

M.M. Aldaya and M.R. Llamas - November 2008

36. The water needed to have Italians eat pasta and pizza

M.M. Aldaya and A.Y. Hoekstra - May 2009

37. The water footprint of Indonesian provinces related to the consumption of crop products

F. Bulsink, A.Y. Hoekstra and M.J. Booij - May 2009

38. The water footprint of sweeteners and bio-ethanol from sugar cane, sugar beet and maize P.W. Gerbens-Leenes and A.Y. Hoekstra - November 2009

39. A pilot in corporate water footprint accounting and impact assessment: The water footprint of a sugar-containing carbonated beverage

A.E. Ercin, M.M. Aldaya and A.Y. Hoekstra - November 2009

40. The green, blue and grey water footprint of rice from both a production and consumption perspective

A.K. Chapagain and A.Y. Hoekstra - March 2010

Reports can be downloaded from:

www.waterfootprint.org

www.unesco-ihe.org/value-of-water-research-report-series 

UNESCO-IHE

P.O. Box 3015

2601 DA Delft

The Netherlands

Website www.unesco-ihe.org

Phone +31152151715

University of Twente

Delft University of Technology
UNESCO-IHE

Institute for Water Education

\section{University of Twente The Netherlands}

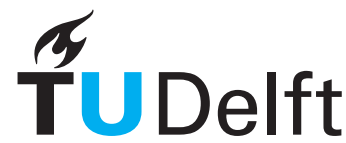

Delft University of Technology 